\title{
A Study of the Effects of Al, Cr, Hf, and Ti Additions on the Microstructure and Oxidation of $\mathrm{Nb}-24 \mathrm{Ti}-18 \mathrm{Si}$ Silicide Based Alloys
}

\author{
Jack Nelson, Mohammad Ghadyani, Claire Utton and Panos Tsakiropoulos * (D) \\ Department of Materials Science and Engineering, Sir Robert Hadfield Building, The University of Sheffield, \\ Mappin Street, Sheffield S1 3JD, UK; pha05jn@gmail.com (J.N.); m.ghadyani@sheffield.ac.uk (M.G.); \\ c.utton@sheffield.ac.uk (C.U.) \\ * Correspondence: p.tsakiropoulos@sheffield.ac.uk
}

Received: 13 June 2018; Accepted: 22 August 2018; Published: 1 September 2018

\begin{abstract}
In} \mathrm{Nb}$-silicide based alloys $\mathrm{Al}, \mathrm{Cr}, \mathrm{Hf}$, and Ti additions are crucial for achieving balance of properties. It is not known how the simultaneous addition of $\mathrm{Hf}$ with $\mathrm{Al}$ and $\mathrm{Ti}$, or $\mathrm{Hf}$ with $\mathrm{Al}$, $\mathrm{Cr}$, and Ti affects macrosegregation, and how the alloying affects hardness, Young's modulus and bulk alloy oxidation, and contamination of the solid solution $\mathrm{Nb}_{\mathrm{ss}}$ and the $\mathrm{Nb}_{5} \mathrm{Si}_{3}$ compound by oxygen. Two alloys with nominal compositions (at.\%) Nb-24Ti-18Si-5Al-5Hf (alloy NbSiTiHf-5Al) and Nb-24Ti-18Si-5Al-5Cr-5Hf (alloy NbSiTiHf-5Al-5Cr) were studied in the as-cast and heat-treated conditions and after isothermal oxidation at 800 and $1200{ }^{\circ} \mathrm{C}$ and were compared with similar alloys without Hf. In both alloys there was macrosegregation of $\mathrm{Si}$ and $\mathrm{Ti}$, which was more severe in NbSiTiHf-5Al. Both alloys formed $\mathrm{Nb}_{\mathrm{ss}}+\beta \mathrm{Nb}_{5} \mathrm{Si}_{3}$ eutectic. The $\mathrm{Nb}_{\mathrm{ss}}$ was stable and its $\mathrm{Al}$ and $\mathrm{Cr}$ concentrations increased with increasing Ti concentration. In both conditions the $\mathrm{NNb}_{5} \mathrm{Si}_{3}$ was observed in the alloys NbSiTiHf-5Al and NbSiTiHf-5Al-5Cr, and the $\gamma \mathrm{Nb}_{5} \mathrm{Si}_{3}$ only in the alloy $\mathrm{NbSiTiHf}-5 \mathrm{Al}$. In both heat-treated alloys, separate $\mathrm{Hf}-\mathrm{rich} \mathrm{Nb}_{5} \mathrm{Si}_{3}$ grains were formed. The $\mathrm{Si}$ and $\mathrm{Al}$ concentrations in $\mathrm{Nb}_{5} \mathrm{Si}_{3}$ respectively decreased and increased with increasing Ti concentration. $\mathrm{Al}$ and $\mathrm{Cr}$ had a stronger hardening effect in the $\mathrm{Nb}_{\mathrm{ss}}$ than $\mathrm{Al}, \mathrm{Cr}$, and $\mathrm{Hf} . \mathrm{Al}, \mathrm{Cr}$, and $\mathrm{Ti}$ had a stronger negative effect on the Young's modulus of the $\mathrm{Nb}_{\mathrm{ss}}$ compared with $\mathrm{Al}, \mathrm{Cr}, \mathrm{Hf}$, and Ti. When $\mathrm{Nb}$ was substituted by $\mathrm{Ti}, \mathrm{Cr}$, and $\mathrm{Hf}$, and $\mathrm{Si}$ by $\mathrm{Al}$ in the $\mathrm{BNb}_{5} \mathrm{Si}_{3}$, the Young's modulus was reduced compared with the unalloyed silicide. At $800{ }^{\circ} \mathrm{C}$ both alloys did not exhibit catastrophic pest-oxidation after $100 \mathrm{~h}$. The $\mathrm{Nb}_{\mathrm{ss}}$ and $\mathrm{Nb}_{5} \mathrm{Si}_{3}$ were contaminated by oxygen in both alloys, the former more severely. At $1200{ }^{\circ} \mathrm{C}$ the scales spalled-off, more severely in the alloy NbSiTiHf- $5 \mathrm{Al}$, where substrate that was heavily contaminated by oxygen below the scale also spalled-off. In both alloys the contamination of $\mathrm{Nb}_{5} \mathrm{Si}_{3}$ and $\mathrm{Nb}_{\mathrm{ss}}$ by oxygen was more severe compared with $800{ }^{\circ} \mathrm{C}$, but the silicides were not contaminated by oxygen in their bulk. The $\mathrm{Nb}_{\mathrm{ss}}$ was not contaminated by oxygen only in the bulk of the alloy NbSiTiHf-5Al-5Cr.
\end{abstract}

Keywords: Niobium alloys; intermetallics; solid solution; oxidation; hardness; Young's modulus

\section{Introduction}

Niobium silicide based alloys can offer a balance of low, intermediate, and high temperature properties and are candidate materials to replace Ni-based superalloys in future aero-engines, to enable the latter to meet environmental and performance targets [1]. The latter have been set by industry and are property goals for new ultra-high temperature alloys with capabilities beyond those of Ni-based superalloys: the room temperature fracture toughness must be above $20 \mathrm{MPa}(\mathrm{m})^{1 / 2}$, there must be less than $1 \%$ creep in $125 \mathrm{~h}$ at $1200{ }^{\circ} \mathrm{C}$ and $\sigma>170 \mathrm{MPa}$ (alloy density $\rho=7 \mathrm{~g} / \mathrm{cm}^{3}$ ), and the oxidation life at 
$1315^{\circ} \mathrm{C}$ must be equal to that of second generation single crystal Ni-based superalloys at $1150{ }^{\circ} \mathrm{C}$ with a short term oxidation goal to have sufficient oxidation resistance in the uncoated condition to survive under typical engine conditions, which requires a loss of material less than $200 \mu \mathrm{m}$ thickness in $10 \mathrm{~h}$ at $1370{ }^{\circ} \mathrm{C}$ and a long term oxidation goal that requires a loss of material less than $25 \mu \mathrm{m}$ thickness in $100 \mathrm{~h}$ at $1315^{\circ} \mathrm{C}$ [1]. Rotor weight savings relative to $\mathrm{Ni}$ superalloy baseline are estimated to be about $20 \%, 22 \%$, and $21 \%$ for $\mathrm{Nb}$-silicide based blades, respectively, in advanced high pressure turbine, current high pressure turbine, and current low pressure turbine [1].

The most important phases in the microstructures of these new alloys are considered to be the bcc $\mathrm{Nb}$ solid solution $\left(\mathrm{Nb}_{\mathrm{ss}}\right)$ and the tetragonal $\mathrm{Nb}_{5} \mathrm{Si}_{3}$ compound. The latter can form as the high temperature $\mathrm{BNb}_{5} \mathrm{Si}_{3}\left(t I 32, \mathrm{~W}_{5} \mathrm{Si}_{3}\right.$-type, $\mathrm{D} 8_{\mathrm{m}}$ ) or the low temperature $\alpha \mathrm{Nb}_{5} \mathrm{Si}_{3}\left(t I 32, \mathrm{Cr}_{5} \mathrm{~B}_{3}\right.$-type, $\left.\mathrm{D} 8_{1}\right)$ silicide and is important for the strength and creep of the alloys. The $\mathrm{Nb}_{\mathrm{ss}}$ is important for the fracture toughness of the alloys and plays a key role in their oxidation and creep properties. A high volume fraction of the $\mathrm{Nb}_{\mathrm{ss}}$ has a negative effect on oxidation resistance, high temperature strength, and creep. A high volume fraction of $\mathrm{Nb}_{5} \mathrm{Si}_{3}$ is desirable for creep resistance but can be detrimental to fracture toughness. Bewlay et al. [1] reviewed the progress on $\mathrm{Nb}$-silicide alloy development till 2002. More recently, one of the authors of this paper reviewed the alloying behaviour and properties of the key phases in $\mathrm{Nb}$-silicide based alloys and showed how such data can be used for the design and/or selection of new alloys [2]. It was also shown that some of the alloy compositions, some of the bcc $\mathrm{Nb}$ solid solution compositions, and some of the $\mathrm{Nb}_{\mathrm{ss}}+\mathrm{Nb}_{5} \mathrm{Si}_{3}$ eutectic compositions satisfy the standard definition of the so called High Entropy Alloys (HEA) [2].

Resistance to oxidation is essential for materials envisioned for high temperature applications in aero-engines. Since the early stages of the development of $\mathrm{Nb}$-silicide based alloys, it was recognized that a research priority should be the improvement of their oxidation. The latter has been achieved with alloy development strategies that used additions of $\mathrm{Al}, \mathrm{Cr}, \mathrm{Hf}$, and Ti individually or simultaneously in $\mathrm{Nb}$-silicide based alloys [2-5]. Improvements of oxidation behaviour have been sought with additions of $\mathrm{B}, \mathrm{Ce}, \mathrm{Ge}$, and $\mathrm{Sn}[3-7]$. As has been the case with Ni-based superalloys, the $\mathrm{Nb}$-silicide based alloys also will require coatings. Coating development has considered $\mathrm{Cr}$ and $\mathrm{Y}$ modified silicide coatings (for example see [8-10]), Mo-Si-Al coatings (for example see [11,12]), and multilayer oxidation resistant coatings (for example see $[13,14]$ ). To date most of the research has been on arc melted alloys that have been studied in their cast and heat-treated conditions. There is very little research on directionally solidified alloys and most of it is on alloys processed using optical floating zone (OFZ) melting. There is even less research on powder metallurgy alloys and on alloys produced using spark plasma sintering [2,15-18].

When added individually to $\mathrm{Nb}, \mathrm{Al}$ and $\mathrm{Cr}$ have a strong effect on its ductile to brittle transition temperature (DBTT), which is increased significantly above $-50^{\circ} \mathrm{C}$, compared with $\mathrm{Hf}$ and Ti that have a weak effect [19]. Aluminium and $\mathrm{Cr}$ were added to $\mathrm{Nb}$-silicide based alloys owing to the properties of their oxides, and Ti because it provides solid solution strengthening to the $\mathrm{Nb}_{\mathrm{ss}}$, significantly improves oxidation [1,2,5,20] and fracture toughness [21], and reduces density [5]. The maximum solid solubility of oxygen in $\mathrm{Nb}$ is about 9 at.\% at $1915^{\circ} \mathrm{C}$ [22]. Hafnium was added to scavenge dissolved oxygen in the alloys [4,5]. High concentrations of $\mathrm{Ti}$ and/or $\mathrm{Hf}$ in the alloy and $\mathrm{Nb}_{5} \mathrm{Si}_{3}$ could stabilise the hexagonal $\gamma \mathrm{Nb}_{5} \mathrm{Si}_{3}\left(h P 16 \mathrm{Mn}_{5} \mathrm{Si}_{3}\right.$-type $\left.\mathrm{D}_{8}\right)$ in the microstructure of $\mathrm{Nb}$-silicide based alloys, which is undesirable owing to its inferior creep compared with the tetragonal $\mathrm{Nb}_{5} \mathrm{Si}_{3}$. When the $\mathrm{Nb} /(\mathrm{Ti}+\mathrm{Hf})$ ratio in the alloy and $\mathrm{Nb}_{5} \mathrm{Si}_{3}$ is less than one, the likelihood of the $\gamma \mathrm{Nb}_{5} \mathrm{Si}_{3}$ being stable increases significantly. Higher values of this ratio are desirable for creep resistance [2,23]. The concentrations of $\mathrm{Al}, \mathrm{Cr}, \mathrm{Hf}$, and $\mathrm{Ti}$ in $\mathrm{Nb}$-silicide based alloys must be optimised in order (i) to achieve a balance of mechanical properties and oxidation, in particular fracture toughness, high temperature strength, and creep and (ii) to suppress pest oxidation.

To date, most of the studied $\mathrm{Nb}$ silicide based alloys with $\mathrm{Al}, \mathrm{Cr}, \mathrm{Hf}$, and Ti additions also had additions of other transition metals, refractory metals, simple metals, and metalloid elements (examples of alloy compositions are given in Supplemental data), which makes it very difficult to clarify how Hf 
affects microstructure, oxidation, and other properties. Bewlay et al. studied different directionally solidified Nb-Ti-Hf-Si alloys with $21<\mathrm{Ti}<33$ at. $\%, 7.5<\mathrm{Hf}<12.5$ at. $\%$, and $0.85<\mathrm{Nb} /(\mathrm{Ti}+\mathrm{Hf})<$ 1.95 and reported a low temperature eutectoid phase transformation of $\mathrm{Nb}_{3} \mathrm{Si}$ to $\mathrm{Nb}_{\mathrm{ss}}$ and hexagonal $\mathrm{hP} 16 \mathrm{Nb}_{5} \mathrm{Si}_{3}$ instead of the $\mathrm{Nb}_{\mathrm{ss}}$ and tetragonal $\mathrm{tI} 32 \mathrm{Nb}_{5} \mathrm{Si}_{3}$ that is observed in binary $\mathrm{Nb}$-Si alloys [24]. The effects on microstructure and properties of the simultaneous addition of (i) $\mathrm{Al}$ and $\mathrm{Ti}$; (ii) $\mathrm{Cr}$ and $\mathrm{Ti}$; (iii) $\mathrm{Al}, \mathrm{Cr}$ and $\mathrm{Ti}$; and (iv) $\mathrm{Hf}$ and $\mathrm{Ti}$ in $\mathrm{Nb}-18 \mathrm{Si}$ silicide based alloys (all compositions in this paper are given in at.\% unless stated otherwise) without other transition and simple metals, and refractory and metalloid element additions were reported in $[5,25,26]$. For example, it was shown that $\mathrm{Al}$ significantly improved the oxidation of the $\mathrm{Nb}-24 \mathrm{Ti}-18 \mathrm{Si}-5 \mathrm{Al}$ alloy at $800{ }^{\circ} \mathrm{C}$ compared with the alloy $\mathrm{Nb}-24 \mathrm{Ti}-18 \mathrm{Si}-5 \mathrm{Cr}$ and suppressed the $\mathrm{Nb}_{3} \mathrm{Si}$ compound and the $\mathrm{Nb}_{\mathrm{ss}}+\mathrm{Nb}_{3}$ Si eutectic that was replaced by the $\mathrm{Nb}_{\mathrm{ss}}+\beta \mathrm{Nb}_{5} \mathrm{Si}_{3}$ eutectic $[25,27]$. However, research has not provided answers to the following questions. (1) How the synergy of $\mathrm{Hf}$ with $\mathrm{Al}$ and $\mathrm{Ti}$, or with $\mathrm{Al}, \mathrm{Cr}$ and $\mathrm{Ti}$ would affect the microstructure and properties of $\mathrm{Nb}$-silicide based alloys? (2) What would be the effect of these synergies on the microstructure, such as macrosegregation of $\mathrm{Si}$, the type of eutectic formed, the prototype of the primary $\mathrm{Nb}_{5} \mathrm{Si}_{3}$, and the alloying behaviour of the $\mathrm{Nb}_{\mathrm{ss}}$ and $\mathrm{Nb}_{5} \mathrm{Si}_{3}$ phases? (3) What would be the effect of these synergies on the oxidation properties of the alloys, or on physical properties such as hardness and Young's modulus? The motivation for the research presented in this paper was to address these three questions by focusing on alloys based on $\mathrm{Nb}-24 \mathrm{Ti}-18 \mathrm{Si}$. The answers to the above questions are essential for the design of new more advanced alloys for high temperature applications [2].

The structure of the paper is as follows. In order to provide answers to each of the above three questions, first new experimental results are presented for two alloys with nominal compositions Nb-24Ti-18Si-5Al-5Hf (alloy NbSiTiHf-5Al) and Nb-24Ti-18Si-5Al-5Cr-5Hf (alloy NbSiTiHf-5Al-5Cr). Then the microstructures and oxidation of these alloys are compared with alloys studied previously. Finally, the effects of alloying additions on the macrosegregation of $\mathrm{Si}$, the chemical composition of the $\mathrm{Nb}_{5} \mathrm{Si}_{3}$ and $\mathrm{Nb}_{\mathrm{ss}}$ and their properties, and the oxidation of the alloys and contamination of phases by oxygen are discussed.

\section{Experimental}

Small buttons (20 g) of the alloys NbSiTiHf-5Al and NbSiTiHf-5Al-5Cr were prepared using high purity elements and arc melting with a non-consumable tungsten electrode and a water cooled copper crucible in an inert atmosphere and were heat treated in an Ar atmosphere for $100 \mathrm{~h}$, as described in [25]. The concentrations of oxygen, carbon, and nitrogen in these alloys were not determined. In arc melted $\mathrm{Nb}$-silicide based alloys studied in our group, typical values of the concentrations of the above elements are in the ranges 0.14 to 0.19 at.\% O, 0.04 to 0.08 at. $\%$ C, and 0.04 to 0.08 at.\% N. Specimens for heat treatment were cut from the bulk of the buttons. The cast and heat treated $\left(1300{ }^{\circ} \mathrm{C} / 100 \mathrm{~h}\right.$ for the alloy NbSiTiHf-5Al and $1500{ }^{\circ} \mathrm{C} / 100 \mathrm{~h}$ for the alloy NbSiTiHf-5Al-5Cr) microstructures were characterised using powder or bulk X-ray diffraction (XRD, Siemens D5000, Hiltonbrooks Ltd, Crew, UK), scanning electron microscopy (SEM, FEI Inspect F50, ThermoFisher Scientific, Hillsboro, OR, USA), SEM with energy dispersive analysis (EDS) with well-polished elemental standards (JEOL 6400, JEOL Ltd., Tokyo, Japan and Philips XL30S, ThermoFisher Scientific, Hillsboro, OR, USA) and electron probe micro-analysis (EPMA, JEOL JXA8230, JEOL Ltd., Tokyo, Japan) with wavelength-dispersive spectroscopy (WDS). The EPMA analyses were carried out as described in [5]. Our group uses EPMA to determine whether the microstructures in the bulk of cast $\mathrm{Nb}$-silicide based alloys are contaminated by oxygen. The phases were determined using WINX ${ }^{\mathrm{POW}}$ software (STOE, Darmstadt, Germany) and ICDD PDF-4+2012 database packages software (ICDD, Newtown Square, PA, USA). The isothermal oxidation of the alloys in air at $800^{\circ} \mathrm{C}$ and $1200{ }^{\circ} \mathrm{C}$ was studied using cubic specimens $\left(3 \times 3 \times 3 \mathrm{~mm}^{3}\right)$ in a NETZSCH STA 49 F3 thermal analyser (NETZSCH GmbH, Selb, Germany). The specimens were cut from the bulk of the cast buttons. 
The microstructures of the oxidised alloys in the bulk and below the scale were also studied in order to assess the contamination of the microstructure by interstitials and whether any of the phases present were immune to this contamination. For the alloy NbSiTiHf-5Al-5Cr, the nano-hardness and Young's modulus of the $\mathrm{Nb}$ solid solution $\left(\mathrm{Nb}_{\mathrm{ss}}\right)$ and $\mathrm{Nb}_{5} \mathrm{Si}_{3}$ were measured as described in [28] using a Berkovitch indenter in a Hysitron Triboscope TS70 nano-mechanical test instrument (Hysitron, Minneapolis, MN, USA) attached to a Veeco dimension 3100 atomic force microscope (Veeco Instruments Inc, Santa Barbara, CA, USA). Serpentine runs, typically $8 \times 8$, were run in areas of the bulk microstructure using a $4000 \mu \mathrm{N}$ load. The microhardness of the phases was measured using a Mitutoyo hardness machine (Mitutoyo America, Aurora, IL, USA) with a load of $0.05 \mathrm{~kg}$.

\section{Results}

\subsection{Cast Alloys}

The actual compositions of the two alloys were Nb-22.3Ti-21.3Si-4.5Al-5.4Hf (alloy NbSiTiHf-5Al) and $\mathrm{Nb}-23.5 \mathrm{Ti}-20.1 \mathrm{Si}-5.5 \mathrm{Al}-4.5 \mathrm{Cr}-5.2 \mathrm{Hf}$ (alloy NbSiTiHf-5Al-5Cr ). Both alloys were richer in $\mathrm{Si}$ compared with their nominal compositions. The cast alloys exhibited macrosegregation of $\mathrm{Si}$ and $\mathrm{Ti}$, the values of which were 7.4 at. $\% \mathrm{Si}$ and 5 at.\% Ti for the alloy NbSiTiHf-5Al, and 4 at.\% Si and 1.9 at.\% Ti for the alloy NbSiTiHf-5Al-5Cr, where the macrosegregation of element $X$ is given as the difference between its maximum and minimum measured concentration (MACX $=C_{\max }-C_{\min }$ ) [29].

The cast microstructures of both alloys consisted of the $\mathrm{Nb}_{\mathrm{ss}}$ and $\mathrm{Nb}_{5} \mathrm{Si}_{3}$ phases and $\mathrm{Nb}_{\mathrm{ss}}+\beta \mathrm{Nb}_{5} \mathrm{Si}_{3}$ eutectic. In both alloys the eutectic was fine and was formed in the top and in the bulk of the buttons. In the bulk the volume fraction of the eutectic was higher. In both alloys no eutectic was observed in the areas of the button where the melt had solidified under the highest cooling rates. There was Hf rich $\mathrm{Nb}_{5} \mathrm{Si}_{3}$ in both alloys and $\mathrm{Hf}$ rich $\mathrm{Nb}_{\mathrm{ss}}$ in the alloy $\mathrm{NbSiTiHf}-5 \mathrm{Al}-5 \mathrm{Cr}$. In the alloy NbSiTiHf-5Al the $\mathrm{Hf}$ rich $\mathrm{Nb}_{5} \mathrm{Si}_{3}$ was observed in the very bottom of the button where the melt was in direct contact with the copper crucible and the "normal" $\mathrm{Nb}_{5} \mathrm{Si}_{3}$ was observed in the transition from bottom to bulk and in the bulk and top of the ingot. The $\mathrm{Hf}$ rich $\mathrm{Nb}_{5} \mathrm{Si}_{3}$ exhibited brighter contrast under back-scatter electron imaging (BSE) compared with the "normal" $\mathrm{Nb}_{5} \mathrm{Si}_{3}$ owing to its higher concentration of Hf. The partitioning of Hf in the microstructures of both alloys made their characterisation using BSE imaging challenging; phases could not be distinguished on the basis of their contrast, in particular the $\mathrm{Nb}_{\mathrm{ss}}$.

The chemical analysis data are given in Tables 1 and 2 for the alloys NbSiTiHf-5Al and NbSiTiHf$5 \mathrm{Al}-5 \mathrm{Cr}$, respectively. The data reported in these Tables were taken from all regions of the cast buttons. Tables 1 and 2 (and Tables S1 and S2 in Supplemental data) give the average concentration, standard deviation, and the minimum and maximum analysis values. The typical microstructure in the bulk of the alloy NbSiTiHf-5Al is shown in Figure 1a. Figure $1 \mathrm{~b}$ shows the microstructure in the bulk of the alloy NbSiTiHf-5Al-5Cr and Figure $1 \mathrm{c}$ to $\mathrm{h}$ show EPMA elemental maps. The powder XRD data confirmed that both $\beta \mathrm{Nb}_{5} \mathrm{Si}_{3}\left(t / 32 \mathrm{~W}_{5} \mathrm{Si}_{3}\right.$-type D8 ${ }_{\mathrm{m}}$ ) and $\gamma \mathrm{Nb}_{5} \mathrm{Si}_{3}\left(h P 16 \mathrm{Mn}_{5} \mathrm{Si}_{3}\right.$-type D8 8 ) were present in the microstructure of the alloy NbSiTiHf-5Al and only the $\beta_{N b} \mathrm{Si}_{3}$ in the alloy JN1 (Figure S1 in Supplemental data). There was no evidence of the $\mathrm{C} 14-\mathrm{NbCr}_{2}$ Laves phase in the $\mathrm{Cr}$ containing alloy NbSiTiHf-5Al-5Cr.

The Hf rich $\mathrm{Nb}_{5} \mathrm{Si}_{3}$ and $\mathrm{Nb}_{\mathrm{ss}}$ can be distinguished in the elemental maps in Figure 1c-h. In these maps the red areas have a higher concentration of the analysed element, and in the blue areas there is little or none of the analysed element. The $\mathrm{Si}$ and $\mathrm{Nb}$ maps clearly show the $\mathrm{Nb}_{5} \mathrm{Si}_{3}$ grains. The $\mathrm{Hf}$ rich regions align with the low $\mathrm{Nb}$ and the high $\mathrm{Si}$ regions, which indicate the $\mathrm{Hf}$ rich $\mathrm{Nb}_{5} \mathrm{Si}_{3}$. The $\mathrm{Hf}$ rich $\mathrm{Nb}_{5} \mathrm{Si}_{3}$ regions were found in between the $\mathrm{Nb}_{5} \mathrm{Si}_{3}$ grains and the $\mathrm{Nb}_{\mathrm{ss}}$. The Ti and $\mathrm{Cr}$ rich regions were also rich in Hf. The $\mathrm{Al}$ map shows that the concentration of this element was higher in the $\mathrm{Nb}_{\mathrm{ss}}$ compared with the $\mathrm{Nb}_{5} \mathrm{Si}_{3}$. The $\mathrm{Cr}$ map does not provide convincing evidence for the presence of the $\mathrm{C} 14-\mathrm{NbCr}_{2}$ Laves phase, with the exception of one area which was also rich in Ti. 
Table 1. SEM-EDS data (at.\%) for the as cast and heat treated alloy Nb-24Ti-18Si-5Al-5Hf (average value, standard deviation, minimum and maximum analysis values).

\begin{tabular}{|c|c|c|c|c|c|}
\hline Alloy \& Phase & $\mathrm{Nb}$ & $\mathrm{Si}$ & $\mathrm{Ti}$ & Al & Hf \\
\hline \multicolumn{6}{|c|}{ As Cast } \\
\hline \multirow{2}{*}{ Average alloy } & $46.2 \pm 2.1$ & $21.3 \pm 1.8$ & $22.3 \pm 1.2$ & $4.5 \pm 0.4$ & $5.4 \pm 0.4$ \\
\hline & $42.1-49.8$ & $18.8-26.2$ & $20.1-25.3$ & $3.5-5.2$ & $4.5-6.0$ \\
\hline \multirow{2}{*}{$\mathrm{Nb}_{\mathrm{sS}}$} & $64.8 \pm 2.9$ & $3.8 \pm 1.2$ & $21.9 \pm 1.6$ & $6.2 \pm 0.2$ & $3.3 \pm 0.3$ \\
\hline & $58.9-68.6$ & $2.5-5.4$ & $19.5-25.7$ & $6.0-6.7$ & $2.9-4.0$ \\
\hline \multirow{2}{*}{$\mathrm{Nb}_{5} \mathrm{Si}_{3}$} & $41.3 \pm 1.2$ & $36.5 \pm 1.4$ & $15.0 \pm 0.3$ & $3.4 \pm 0.3$ & $3.8 \pm 0.3$ \\
\hline & $40.5-44.5$ & $34.1-38.5$ & $14.0-15.5$ & $3.0-3.9$ & $3.6-4.4$ \\
\hline \multirow{2}{*}{ Hf rich $\mathrm{Nb}_{5} \mathrm{Si}_{3}$} & $36.2 \pm 2.2$ & $36.1 \pm 1.5$ & $17.7 \pm 3.0$ & $2.9 \pm 0.4$ & $6.9 \pm 0.5$ \\
\hline & $31.5-38.1$ & $32.7-37.5$ & $15.9-24.7$ & $2.5-3.8$ & $6.5-7.8$ \\
\hline \multirow{2}{*}{$\mathrm{Nb}_{\mathrm{ss}}+\beta \mathrm{Nb}_{5} \mathrm{Si}_{3}$ eutectic } & $52.6 \pm 2.4$ & $15.5 \pm 1.2$ & $22.1 \pm 2.1$ & $5.1 \pm 0.4$ & $4.6 \pm 0.3$ \\
\hline & $49.3-57.8$ & $12.1-17.9$ & $18.5-26.1$ & $4.5-5.7$ & $3.9-5.2$ \\
\hline \multicolumn{6}{|c|}{ Heat Treated } \\
\hline \multirow{2}{*}{ Average alloy } & $48.0 \pm 1.9$ & $20.5 \pm 2.6$ & $21.3 \pm 1.2$ & $4.3 \pm 0.4$ & $5.7 \pm 0.3$ \\
\hline & $44.5-51.6$ & $16.3-25.4$ & $19.2-25.1$ & $3.4-5.1$ & $5.1-6.4$ \\
\hline \multirow{2}{*}{$\mathrm{Nb}_{\mathrm{ss}}$} & $68.2 \pm 2.5$ & $0.9 \pm 0.3$ & $22.6 \pm 2.5$ & $6.1 \pm 0.5$ & $2.1 \pm 0.3$ \\
\hline & $65.8-75.5$ & $0.4-1.5$ & $14.7-24.1$ & $4.1-7.0$ & $1.4-2.6$ \\
\hline \multirow{2}{*}{ Hf rich $\mathrm{Nb}_{5} \mathrm{Si}_{3}\left(\right.$ bulk $\left.{ }^{*}\right)$} & $34.0 \pm 1.1$ & $36.3 \pm 1.4$ & $20.5 \pm 0.6$ & $3.8 \pm 0.1$ & $5.4 \pm 0.1$ \\
\hline & $33.2-34.8$ & $35.2-37.3$ & $20.1-20.9$ & $3.8-3.9$ & $5.3-5.5$ \\
\hline \multirow{2}{*}{$\mathrm{Nb}_{5} \mathrm{Si}_{3}$} & $42.8 \pm 1.0$ & $34.4 \pm 0.6$ & $15.7 \pm 1.2$ & $3.1 \pm 0.4$ & $3.7 \pm 0.3$ \\
\hline & $41.3-43.9$ & $33.5-35.1$ & $14.4-17.5$ & $2.5-3.6$ & $3.3-4.2$ \\
\hline \multirow{2}{*}{ Hf rich $\mathrm{Nb}_{5} \mathrm{Si}_{3}\left(\right.$ bottom ${ }^{*}$ ) } & $35.7 \pm 3.1$ & $35.8 \pm 2.1$ & $18.2 \pm 3.1$ & $2.9 \pm 0.6$ & $7.4 \pm 0.7$ \\
\hline & $27.9-38.6$ & $30.7-38.0$ & $14.5-24.6$ & $2.0-4.1$ & $6.3-8.6$ \\
\hline \multirow{2}{*}{ Prior eutectic } & $48.7 \pm 1.4$ & $17.7 \pm 1.2$ & $23.4 \pm 0.6$ & $4.7 \pm 0.3$ & $5.5 \pm 0.2$ \\
\hline & $46.2-51.7$ & $15.2-19.4$ & $22.4-23.9$ & $4.4-5.1$ & $5.2-5.9$ \\
\hline
\end{tabular}

Table 2. EPMA data (at.\%) for the as cast and heat treated alloy Nb-24Ti-18Si-5Al-5Cr-5Hf (average value, standard deviation, minimum and maximum analysis values).

\begin{tabular}{|c|c|c|c|c|c|c|}
\hline Alloy \& Phase & $\mathrm{Nb}$ & $\mathrm{Si}$ & $\mathrm{Ti}$ & $\mathrm{Cr}$ & Al & Hf \\
\hline \multicolumn{7}{|c|}{ As Cast } \\
\hline \multirow{2}{*}{ Average alloy } & $41.2 \pm 0.6$ & $20.1 \pm 1.0$ & $23.5 \pm 0.5$ & $4.5 \pm 0.3$ & $5.5 \pm 0.2$ & $5.2 \pm 0.2$ \\
\hline & $40.4-42.4$ & $17.7-21.7$ & $22.6-24.5$ & $4.0-5.0$ & $5.0-5.9$ & $5.0-5.6$ \\
\hline \multirow{2}{*}{$\mathrm{Nb}_{\mathrm{ss}}$} & $53.7 \pm 3.2$ & $1.7 \pm 0.4$ & $26.5 \pm 1$ & $8.0 \pm 1.1$ & $6.2 \pm 0.2$ & $3.6 \pm 0.7$ \\
\hline & $48.7-57.0$ & $1.3-2.5$ & $924.7-29.5$ & $6.7-9.3$ & $6.2-6.8$ & $3.0-4.5$ \\
\hline \multirow{2}{*}{ Hf rich $\mathrm{Nb}_{\mathrm{ss}}$} & $45.9 \pm 4.0$ & $2.0 \pm 0.7$ & $30.7 \pm 1.7$ & $9.4 \pm 1.0$ & $6.5 \pm 0.2$ & $5.5 \pm 0.7$ \\
\hline & $40.6-51.8$ & $1.3-3.5$ & $28.1-33.4$ & $7.5-11.1$ & $6.2-6.8$ & $4.7-6.4$ \\
\hline \multirow{2}{*}{$\mathrm{Nb}_{5} \mathrm{Si}_{3}$} & $41.0 \pm 1.4$ & $30.4 \pm 1.2$ & $19.2 \pm 1.4$ & $1.3 \pm 0.5$ & $3.5 \pm 0.5$ & $4.6 \pm 0.1$ \\
\hline & $38.8-42.6$ & $28.2-31.5$ & $17.8-20.8$ & $0.9-2.3$ & $3.0-4.2$ & $4.4-4.7$ \\
\hline \multirow{2}{*}{ Hf rich $\mathrm{Nb}_{5} \mathrm{Si}_{3}$} & $30.4 \pm 0.6$ & $32.6 \pm 0$ & $23.7 \pm 0.1$ & $1.1 \pm 0.4$ & $2.9 \pm 0.1$ & $9.3 \pm 0.3$ \\
\hline & $30.1-31.3$ & $931.2-33.3$ & $23.5-23.7$ & $0.9-1.8$ & $2.8-3.0$ & $8.9-9.5$ \\
\hline \multirow{2}{*}{$\mathrm{Nb}_{\mathrm{ss}}+\beta \mathrm{Nb}_{5} \mathrm{Si}_{3}$ eutectic } & $46.8 \pm 2.2$ & $13.3 \pm 1.5$ & $24.2 \pm 1.1$ & $5.3 \pm 0.6$ & $5.6 \pm 0.2$ & $4.8 \pm 0.5$ \\
\hline & $44.1-49.2$ & $12.0-14.9$ & $23.2-25.5$ & $4.8-6.1$ & $5.2-6.0$ & $4.6-4.9$ \\
\hline \multicolumn{7}{|c|}{ Heat Treated } \\
\hline \multirow{2}{*}{ Average alloy } & $43.1 \pm 1.0$ & $19.3 \pm 1.8$ & $24.1 \pm 0.8$ & $4.1 \pm 0.5$ & $3.8 \pm 0$ & $5.7 \pm 0.3$ \\
\hline & $42.2-44.7$ & $15.3-21.2$ & $22.9-25.1$ & $3.5-5.0$ & $92.5-4.9$ & $5.3-6.0$ \\
\hline \multirow{2}{*}{$\mathrm{Nb}_{\mathrm{ss}}$} & $53.7 \pm 0.8$ & $0.5 \pm 0.1$ & $27.0 \pm 0.1$ & $9.4 \pm 0.3$ & $7.1 \pm 0.7$ & 2.2 \\
\hline & $53.1-54.9$ & $0.5-0.8$ & $26.9-27.2$ & $9.0-9.8$ & $6.1-7.7$ & $2.1-2.2$ \\
\hline \multirow{2}{*}{$\mathrm{Nb}_{5} \mathrm{Si}_{3}$} & $40.9 \pm 0.3$ & $33.3 \pm 0.2$ & $18.2 \pm 0.2$ & 0.5 & $1.7 \pm 0.1$ & $5.4 \pm 0.2$ \\
\hline & $40.6-41.2$ & $33.1-33.6$ & $17.9-18.5$ & $0.4-0.5$ & $1.6-1.8$ & $5.2-5.7$ \\
\hline \multirow{2}{*}{$\mathrm{Hf}$ rich ${ }^{*} \mathrm{Nb}_{5} \mathrm{Si}_{3} *$} & $27.3 \pm 0.3$ & $32.5 \pm 0.1$ & $26.6 \pm 0.1$ & 1.2 & $3.1 \pm 0.2$ & $9.3 \pm 0.1$ \\
\hline & $27.1-27.9$ & $32.3-32.7$ & $26.3-26.7$ & $1.2-1.3$ & $2.7-3.3$ & $9.0-9.5$ \\
\hline \multirow{2}{*}{ Hf poor ${ }^{*} \mathrm{Nb}_{5} \mathrm{Si}_{3} *$} & $41.3 \pm 0.1$ & $32.0 \pm 0.3$ & $18.8 \pm 0.1$ & 0.6 & $2.7 \pm 0.3$ & $4.6 \pm 0.1$ \\
\hline & $41.2-41.5$ & $31.4-32.4$ & $18.7-18.8$ & $0.5-0.7$ & $2.4-3.2$ & $4.5-4.7$ \\
\hline
\end{tabular}



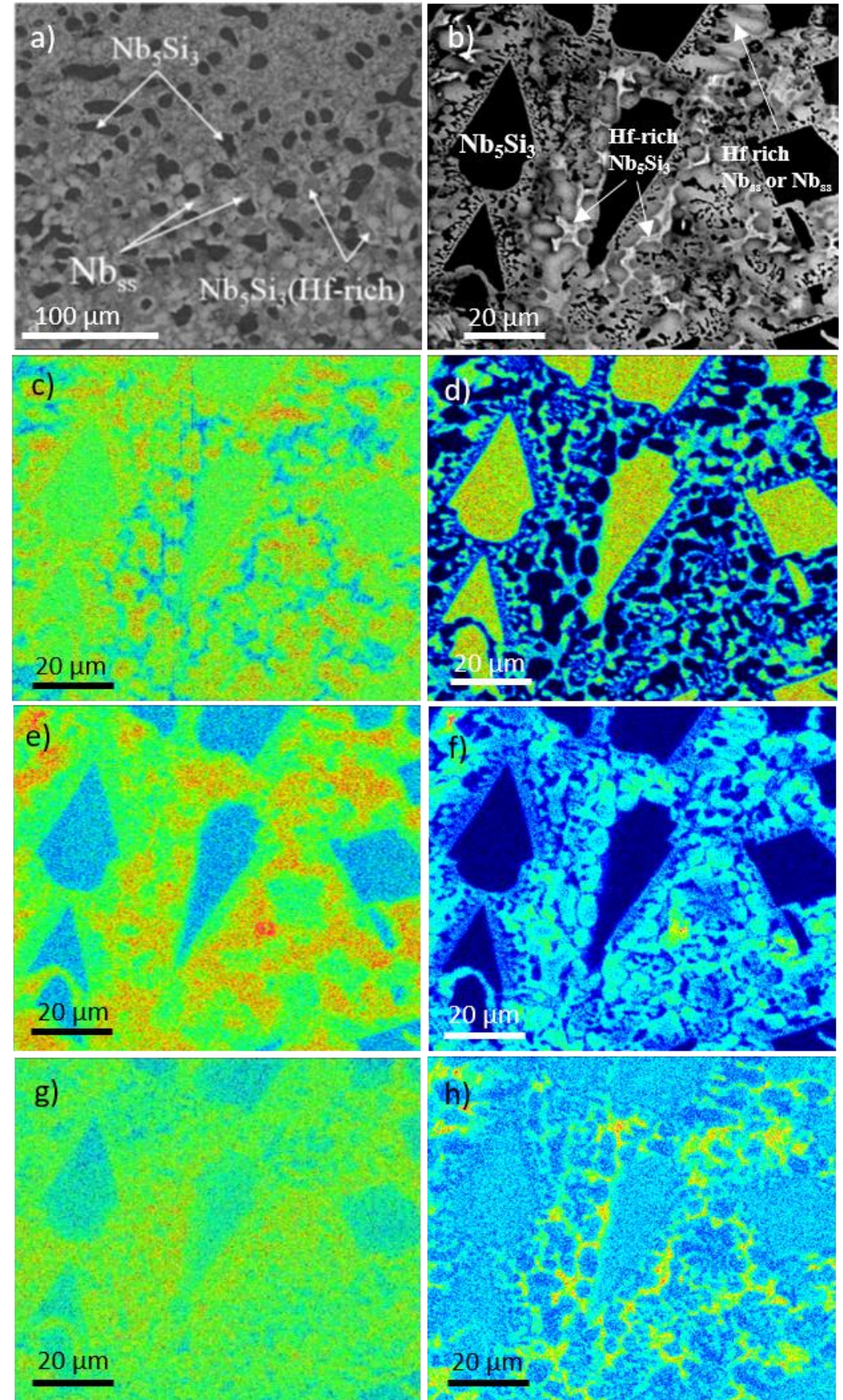

Figure 1. BSE images of the bulk of the cast alloys NbSiTiHf-5Al (a) and NbSiTiHf-5Al-5Cr (b) and EPMA X-ray maps corresponding to (b) where (c) $\mathrm{Nb}$, (d) $\mathrm{Si}$, (e) $\mathrm{Ti}$, (f) $\mathrm{Cr}$, (g) $\mathrm{Al}$ and (h) $\mathrm{Hf}$.

The $\mathrm{Al}$ and $\mathrm{Hf}$ concentrations in the $\mathrm{Nb}_{\mathrm{ss}}$ were essentially the same in the two alloys, and the concentrations of $\mathrm{Cr}$ and $\mathrm{Ti}$ increased in the Hf-rich $\mathrm{Nb}_{\mathrm{ss}}$ in the alloy NbSiTiHf-5Al-5Cr . The concentrations of $\mathrm{Al}$ in the $\mathrm{Nb}_{5} \mathrm{Si}_{3}$ and $\mathrm{Hf}$ rich $\mathrm{Nb}_{5} \mathrm{Si}_{3}$ were the same in both alloys but those of $\mathrm{Hf}$ and Ti were higher in the alloy NbSiTiHf-5Al-5Cr. The Al+Si concentration of the eutectic was 20.6 and 18.9 at. $\%$ in the alloys NbSiTiHf-5Al and NbSiTiHf-5Al-5Cr, respectively. 


\subsection{Heat Treated Alloys}

After the heat treatments the average compositions of the heat treated specimens were $\mathrm{Nb}-21.3 \mathrm{Ti}-20.5 \mathrm{Si}-4.3 \mathrm{Al}-5.7 \mathrm{Hf}$ and $\mathrm{Nb}-24.1 \mathrm{Ti}-19.3 \mathrm{Si}-3.8 \mathrm{Al}-4.1 \mathrm{Cr}-5.7 \mathrm{Hf}$, respectively, for the alloys $\mathrm{NbSiTiHf}-5 \mathrm{Al}$ and NbSiTiHf-5Al-5Cr (see Tables 1 and 2). In both alloys chemical inhomogeneity of Si and Ti was still present and the concentrations of these elements were in the ranges 25.4 to 16.3 at.\% Si and 25.1 to 19.2 at.\% Ti in the alloy NbSiTiHf-5Al, and 21.2 to 15.3 at.\% Si and 25.1 to 22.9 at.\% Ti in the alloy NbSiTiHf-5Al-5Cr.

The phases present in the heat treated alloys were the same as in the cast alloys (Figure S1 in Supplemental data). The microstructure of the alloy NbSiTiHf-5Al (Figure 2) was similar to that shown in Figure 1a. Prior eutectic areas could still be seen only in the bulk of the alloy NbSiTiHf-5Al where the $\mathrm{Al}+\mathrm{Si}$ concentration was 22.4 at.\%. There was no $\mathrm{Hf}$ rich $\mathrm{Nb}_{\mathrm{ss}}$ in the alloy NbSiTiHf-5Al-5Cr but in both alloys the partitioning of $\mathrm{Hf}$ and $\mathrm{Ti}$ in $\mathrm{Nb}_{5} \mathrm{Si}_{3}$ had progressed further resulting in the formation of discrete $\mathrm{Hf}$ rich $\mathrm{Nb}_{5} \mathrm{Si}_{3}$ grains, particularly in the alloy $\mathrm{NbSiTiHf}-5 \mathrm{Al}-5 \mathrm{Cr}$ (see Figure 2). Precipitation of a second phase in the $\mathrm{Nb}_{5} \mathrm{Si}_{3}$ was not observed in both the heat treated alloys.

In the heat treated alloy NbSiTiHf-5Al, the Ti and Hf concentrations in the Hf rich $\mathrm{Nb}_{5} \mathrm{Si}_{3}$ were the same as in the cast alloy. However, in the "normal" $\mathrm{Nb}_{5} \mathrm{Si}_{3}$ in the bulk of the heat treated alloy the Ti concentration had increased compared with the cast alloy, as did the Hf concentration. In other words, as a result of the heat treatment the $\mathrm{Nb}_{5} \mathrm{Si}_{3}$ in the alloy NbSiTiHf-5Al tended to become richer in Ti and Hf.

In the heat treated alloy NbSiTiHf-5Al-5Cr, the partitioning of $\mathrm{Hf}$ led to the formation of $\mathrm{Hf}$ rich $\mathrm{Nb}_{5} \mathrm{Si}_{3}$, Hf poor $\mathrm{Nb}_{5} \mathrm{Si}_{3}$, and "normal" $\mathrm{Nb}_{5} \mathrm{Si}_{3}$; each had different composition and was observed in different locations within the microstructure. The Hf rich phase formed as discrete grains, see Figure 2. The Hf poor $\mathrm{Nb}_{5} \mathrm{Si}_{3}$ was found in the bulk of $\mathrm{Nb}_{5} \mathrm{Si}_{3}$ owing to incomplete homogenisation and diffusion of $\mathrm{Hf}$ from the surrounding $\mathrm{Nb}_{\mathrm{ss}}$.

The elemental maps in Figure 2 show the dispersion and partitioning of elements within the microstructure of the heat treated alloy NbSiTiHf-5Al-5Cr. In these maps the red areas have a higher concentration of the analysed element, and in the blue areas there is little or none of the analysed element. The $\mathrm{Nb}$ map in conjunction with the Hf map shows that in areas of low $\mathrm{Nb}$, the Hf levels were higher. This relationship between $\mathrm{Nb}$ and $\mathrm{Hf}$ (see discussion), when compared with the Si map, is due to the partitioning effect of $\mathrm{Hf}$ within the $\mathrm{Nb}_{5} \mathrm{Si}_{3}$. Titanium can be seen to be partitioning primarily to the phases that are rich in Hf. The Cr concentration is predominantly higher in the $\mathrm{Nb}_{\mathrm{ss}}$ and is very low in the $\mathrm{Nb}_{5} \mathrm{Si}_{3}$ and $\mathrm{Hf}$-poor $\mathrm{Nb}_{5} \mathrm{Si}_{3}$ grains. As would be expected, the $\mathrm{Cr}$ concentration in the Hf-rich $\mathrm{Nb}_{5} \mathrm{Si}_{3}$ was slightly higher due to the affinity of $\mathrm{Cr}$ with $\mathrm{Ti}$ and $\mathrm{Hf}$. The $\mathrm{Al}$ concentration was fairly constant throughout the alloy with a slightly higher concentration in the $\mathrm{Nb}_{\mathrm{ss}}$ and Hf-rich $\mathrm{Nb}_{5} \mathrm{Si}_{3}$. In the $\mathrm{Nb}$ and $\mathrm{Si}$ maps (Figure $2 \mathrm{c}, \mathrm{d}$ ) the areas of lower $\mathrm{Nb}$ and higher Si show the "halo effect" around the outside of the $\mathrm{Hf}$ rich $\mathrm{Nb}_{5} \mathrm{Si}_{3}$ (see Figure 2c). This increase in $\mathrm{Si}$ and decrease in $\mathrm{Nb}$ may suggest that the Hf-rich $\mathrm{Nb}_{5} \mathrm{Si}_{3}$ was still growing and these boundary areas were representative of an intermediate growth stage which heralds the progression of the $\mathrm{Nb}_{5} \mathrm{Si}_{3} / \mathrm{Nb}_{\mathrm{ss}}$ interface and the consumption of $\mathrm{Nb}_{\mathrm{ss}}$.

In the $\mathrm{Nb}_{\mathrm{ss}}$ the average Si concentration was reduced to a value that is consistent with other data in the literature for heat treated $\mathrm{Nb}$-silicide based alloys, see Tables 1 and $2[25,26]$. The partitioning of $\mathrm{Hf}$ in the microstructure as well as its consumption to form hafnia $\left(\mathrm{HfO}_{2}\right)$ led to a drop in the overall Hf concentration within the $\mathrm{Nb}_{\mathrm{ss}}$ in both alloys after the heat treatment (Tables 1 and 2). However, in the bulk of the alloy NbSiTiHf-5Al the Ti concentrations in the $\mathrm{Nb}_{\mathrm{ss}}$ varied between 14.7 and 24.1 at.\%.

There was contamination by nitrogen and oxygen near the top and bottom surfaces of the heat treated alloy NbSiTiHf-5Al where TiN and $\mathrm{HfO}_{2}$ were formed but not in the bulk. Hafnia was also observed in the heat treated alloy NbSiTiHf-5Al-5Cr. The data for the alloy NbSiTiHf-5Al would suggest that the synergy of $\mathrm{Al}$ and $\mathrm{Hf}$ was effective in decreasing the diffusivity of interstitials to the bulk of the alloy, in agreement with [30]. 

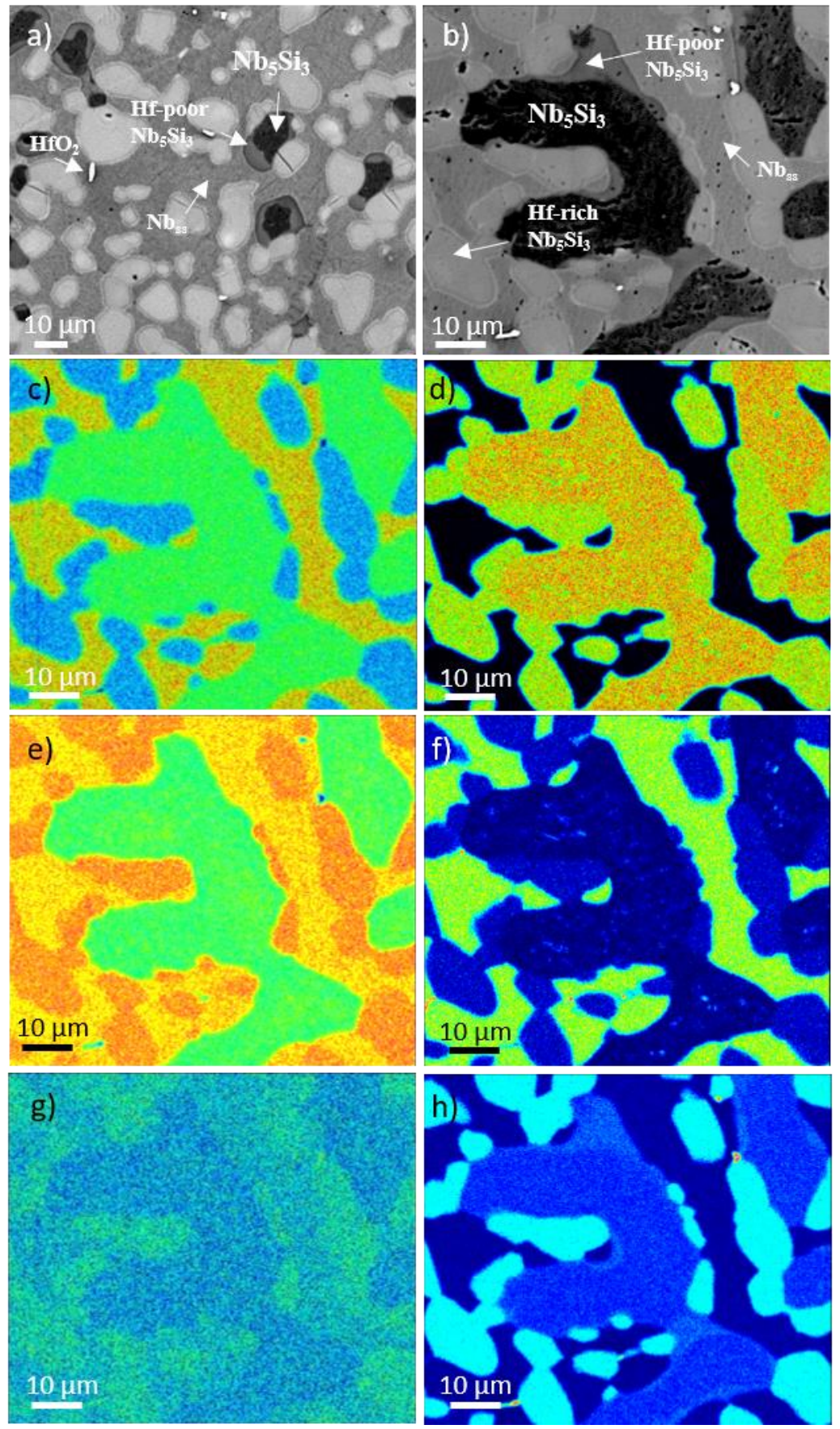

Figure 2. BSE images (a) and (b) of the heat treated microstructure of the alloy NbSiTiHf-5Al-5Cr and EPMA X-ray maps corresponding to (b) of (c) Nb, (d) $\mathrm{Si}$, (e) $\mathrm{Ti},(\mathbf{f}) \mathrm{Cr}$, (g) $\mathrm{Al}$ and (h) Hf.

\subsection{Oxidation at $800^{\circ} \mathrm{C}$}

After $100 \mathrm{~h}$ oxidation in air at $800{ }^{\circ} \mathrm{C}$ both alloys did not suffer from catastrophic pest oxidation (Figure S2 in Supplemental data), but there were differences in their oxidation behaviour. The alloy NbSiTiHf-5Al had followed parabolic oxidation kinetics with $\mathrm{k}_{\mathrm{p}}=4 \times 10^{-10} \mathrm{~g}^{2} / \mathrm{cm}^{4} \mathrm{~s}$ and after $100 \mathrm{~h}$ its mass gain was $0.0114 \mathrm{~g} / \mathrm{cm}^{2}$ (Figure S4a in Supplemental data) The alloy NbSiTiHf-5Al-5Cr had followed linear oxidation kinetics with $\mathrm{k}_{1}=1 \times 10^{-8} \mathrm{~g} / \mathrm{cm}^{2} \mathrm{~s}$ and had gained mass $0.005 \mathrm{~g} / \mathrm{cm}^{2}$ (Figure S5a in Supplemental data) There was no spallation of the scale formed on the alloy $\mathrm{NbSiTiHf}-5 \mathrm{Al}$, and no oxide powder was observed near the specimen. However, there was evidence 
of scale detachment from the edge of the NbSiTiHf-5Al specimen. The oxidised specimen of the alloy $\mathrm{NbSiTiHf}-5 \mathrm{Al}-5 \mathrm{Cr}$ was generally intact. The scale that was formed on the alloy NbSiTiHf-5Al-5Cr was very brittle and easily crumbled into a powder; there was also a very small amount of oxide powder around the specimen after the isothermal oxidation experiment, which indicated early stages of pest oxidation. The weight gain data (Figures S4a and S5a in Supplemental data) and the morphology of the oxidised specimen indicated that there was no breakaway oxidation.

Figure 3 shows images of the surface of the alloy NbSiTiHf-5Al-5Cr after oxidation at $800{ }^{\circ} \mathrm{C}$. In Figure $3 \mathrm{~b}$ the phases below the scale are indicated. The silicide can be clearly seen surrounded by oxidised $\mathrm{Nb}_{\mathrm{ss}}$ (Figure 3a); the silicide itself was covered with fine needle-like oxide (Figure 3c). The $\mathrm{Nb}_{5} \mathrm{Si}_{3}$ displayed trans-granular and inter-granular cracking (Figure 3a) that was attributed to the strain induced by oxide growth $[3,4]$ and the low toughness of $\mathrm{Nb}_{5} \mathrm{Si}_{3}[31]$.

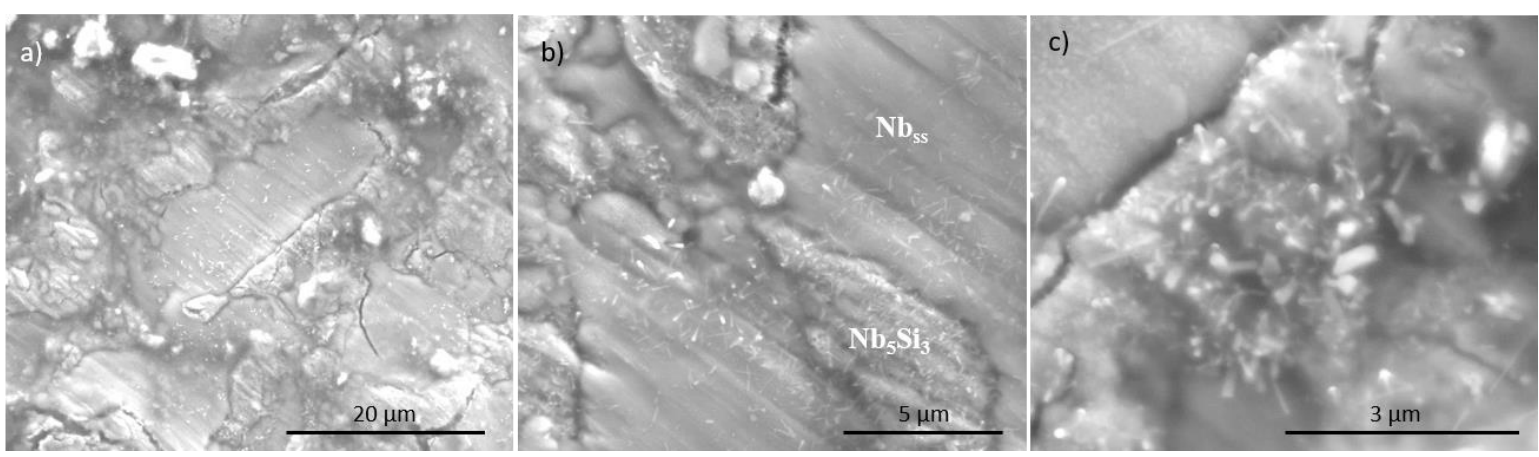

Figure 3. BSE images of scale on the surfaces of the alloy JN1 after isothermal oxidation at $800{ }^{\circ} \mathrm{C}$, (a) showing overview of surface and (b) and (c) showing detail. The phases below the scale are indicated in (b).

Cross sections of the oxidised specimen of the alloys NbSiTiHf-5Al-5Cr and NbSiTiHf-5Al respectively are shown in Figure 4 and in Figure S6a in the Supplemental data. The diffusion zone [5] extended about $75 \mu \mathrm{m}$ below the surface of the alloy NbSiTiHf-5Al-5Cr and there was cracking throughout the diffusion zone parallel to the oxide surface. This type of cracking is attributed to the voluminous oxide formation from the oxidation of the $\mathrm{Nb}_{\mathrm{ss}}$, inducing tensile stresses in the low fracture toughness $\mathrm{Nb}_{5} \mathrm{Si}_{3}$ causing the latter to crack, and influences oxidation kinetics as reported before, for example see $[4,5]$. The cracks had travelled predominantly through the $\mathrm{Nb}_{5} \mathrm{Si}_{3}$ grains rather than the embrittled $\mathrm{Nb}_{\mathrm{ss}}$ and oxides. The details of the microstructure shown in Figure 4 are essentially the same as those reported in [5] for the cast alloy JG4 (=Nb-24Ti-18Si-5Al-5Cr-5Hf-2Mo) after oxidation at $800{ }^{\circ} \mathrm{C}$. The diffusion zone, in which the $\mathrm{Nb}_{5} \mathrm{Si}_{3}$ was cracked, comprised of $\mathrm{Nb}_{5} \mathrm{Si}_{3}$, heavily contaminated $\mathrm{Nb}_{\mathrm{ss}}$, and a mixed oxide. The alloy below the diffusion zone was comprised of the same phases as the cast alloy before oxidation, however with oxygen contamination (Table S1 in Supplemental data). It should be noted that the phases were not contaminated by oxygen (EPMA data) in the bulk of the cast alloy.

For the oxidised alloy NbSiTiHf-5Al-5Cr the EPMA analysis data was collected from the diffusion zone, $30 \mu \mathrm{m}$ below the diffusion zone, and the bulk of the alloy in order to determine how deep the contamination by oxygen was. The diffusion zone was comprised of $\mathrm{Nb}_{5} \mathrm{Si}_{3}$ and a mixed oxide, the constituent phases of which are unknown. Compared with the cast alloy (Table 2) the $\mathrm{Nb}_{5} \mathrm{Si}_{3}$ showed little to no affinity for oxygen, with a low (0.4 at.\%) concentration of oxygen in the diffusion zone and 0 at.\% oxygen below the diffusion zone and in the bulk (Table S1 in Supplemental data). The latter is in agreement with the results reported in [5] for the alloy JG4 (=Nb-24Ti-18Si-5Al-5Cr-5Hf-2Mo). However, the $\mathrm{Nb}_{\mathrm{ss}}$ in the alloy NbSiTiHf-5Al-5Cr had been contaminated and had an oxygen concentration of 1.4 at.\% in the diffusion zone, which decreased towards the bulk of the alloy where the oxygen concentration was 0.8 at.\% (Table S1 in Supplemental data). This confirmed that 
oxygen had contaminated (reached) the bulk of the alloy. The oxygen concentration in the $\mathrm{Nb}_{\mathrm{ss}}$ was below the maximum solid solubility of oxygen in $\mathrm{Nb}_{\mathrm{ss}}$ owing to the formation of $\mathrm{HfO}_{2}$ in the microstructure. Contamination of the $\mathrm{Nb}_{\mathrm{ss}}$ and $\mathrm{Nb}_{5} \mathrm{Si}_{3}$ was observed in the diffusion zone and bulk of the alloy NbSiTiHf-5Al.

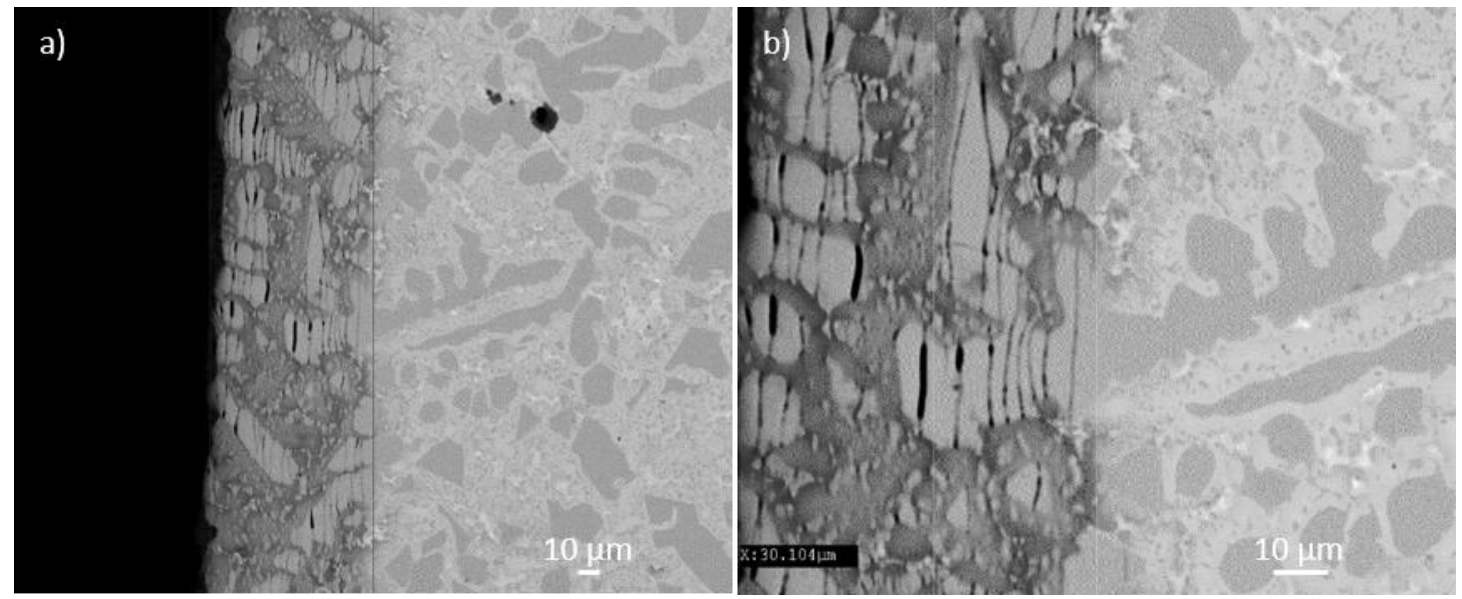

Figure 4. BSE image of cross sections of the alloy NbSiTiHf-5Al-5Cr after isothermal oxidation at $800{ }^{\circ} \mathrm{C}$ showing cracks in the diffusion zone. (a) overview, (b) detailed view.

\subsection{Oxidation at $1200^{\circ} \mathrm{C}$}

After $100 \mathrm{~h}$ oxidation in air at $1200{ }^{\circ} \mathrm{C}$ the alloy NbSiTiHf-5Al exhibited spallation of its scale (Figure S3a in Supplemental data). The spalled scale consisted of 12 layers uniformly separated after the oxidation; in other words, two layers had spalled-off from each side of the specimen. The layers could easily be crushed into powder after the oxidised specimen was removed from the crucible. There was also spallation of the scale that formed on the alloy NbSiTiHf-5Al-5Cr, however some parts of the scale remained attached, particularly near the edge of the specimen (Figure S3b in Supplemental data).

Powder XRD data (Figure S7b in Supplemental data) taken from the spalled layers of the scale formed on the alloy $\mathrm{NbSiTiHf}-5 \mathrm{Al}$ suggested that Ti niobates, $\mathrm{HfO}_{2}$, and $\mathrm{Nb}_{2} \mathrm{O}_{5}, \mathrm{SiO}_{2}$, and $\mathrm{TiO}_{2}$ [2] were the oxides in the scale (the same oxides as in the scale formed at $800^{\circ} \mathrm{C}$, Figure S7a in Supplemental data) and also indicated the presence of tetragonal and hexagonal $\mathrm{Nb}_{5} \mathrm{Si}_{3}$, which suggested that part of the spalled-off material included heavily contaminated substrate below the alloy scale.

For both alloys there were no sudden weight gains or losses during oxidation (Figures S4b and S5b in Supplemental data); this indicated a stable oxide growth with no breakaway oxidation during isothermal oxidation. The mass gain of the alloy NbSiTiHf- $5 \mathrm{Al}$ was $0.026 \mathrm{~g} / \mathrm{cm}^{2}$, and the alloy followed parabolic kinetics in the early stages $(<20 \mathrm{~h})$ with $\mathrm{k}_{\mathrm{p}}=6 \times 10^{-8} \mathrm{~g}^{2} / \mathrm{cm}^{4} \mathrm{~s}$ and then linear kinetics with $\mathrm{k}_{1}=1 \times 10^{-9} \mathrm{~g} / \mathrm{cm}^{2} \mathrm{~s}$ (Figure S4b in Supplemental data). The mass gain of the alloy NbSiTiHf-5Al-5Cr was $0.05 \mathrm{~g} / \mathrm{cm}^{2}$. The alloy followed parabolic oxidation kinetics with $\mathrm{k}_{\mathrm{p}}=7 \times 10^{-9} \mathrm{~g}^{2} / \mathrm{cm}^{4} \mathrm{~s}$ during the whole duration of the isothermal oxidation experiment (Figure S5b in Supplemental data).

Unlike the alloy NbSiTiHf-5Al-5Cr oxidised at $800{ }^{\circ} \mathrm{C}$, at $1200{ }^{\circ} \mathrm{C}$ the $\mathrm{Nb}_{5} \mathrm{Si}_{3}$ grains could no longer be clearly distinguished below the scale. The latter exhibited globular morphology, appeared to have some porosity and cracks and most likely consisted of Ti and $\mathrm{Cr}$ niobates, $\mathrm{HfO}_{2}$, and $\mathrm{Nb}_{2} \mathrm{O}_{5}$ [2,5]. Typical images of cross sections of the oxidised alloy NbSiTiHf-5Al-5Cr can be seen in the Figure 5 , which shows the depth of the diffusion zone (about $600 \mu \mathrm{m}$, Figure 5a), different phases in the diffusion zone (Figure $5 b, c)$, and details of the diffusion zone/oxide layer interface (Figure $5 \mathrm{~d}$ ). The diffusion zone consisted of three distinct regions. Closest to the oxide layer was region $\mathrm{A}$, which was up to about $100 \mu \mathrm{m}$ deep; this was a dense region consisting of oxides/nitrides and $\mathrm{Nb}_{5} \mathrm{Si}_{3}$ grains. Next was region $\mathrm{B}$, which was about $100-350 \mu \mathrm{m}$ deep and contained $\mathrm{Nb}_{\mathrm{ss}}, \mathrm{Nb}_{5} \mathrm{Si}_{3}$, TiO/TiN (black contrast 
phase), and $\mathrm{HfO}_{2}$ (white contrast phase), and finally region $\mathrm{C}$ that was about 250-800 $\mu \mathrm{m}$ deep and consisted of $\mathrm{Nb}_{\mathrm{ss}}, \mathrm{Nb}_{5} \mathrm{Si}_{3}$, and $\mathrm{HfO}_{2}$. The phases in region A could not be analysed using WDS, though similarities in contrast would suggest that it comprised of $\mathrm{TiO} / \mathrm{TiN}$ and $\mathrm{HfO}_{2}$. There were several regions of different contrast which indicated the likely formation of a third oxide but it was not possible to analyse this phase. Due to the low $\mathrm{Nb}$ concentrations in the areas where titanium oxide(s) and/or nitride and $\mathrm{HfO}_{2}$ were formed, it is unlikely that a $\mathrm{Nb}$-based oxide formed there. A cross section of the alloy NbSiTiHf-5Al is shown in Figure S6b in Supplemental data. There was spallation of the scales formed on both alloys, thus the presence or absence of cracking below the scale at $1200{ }^{\circ} \mathrm{C}$ cannot be confirmed.

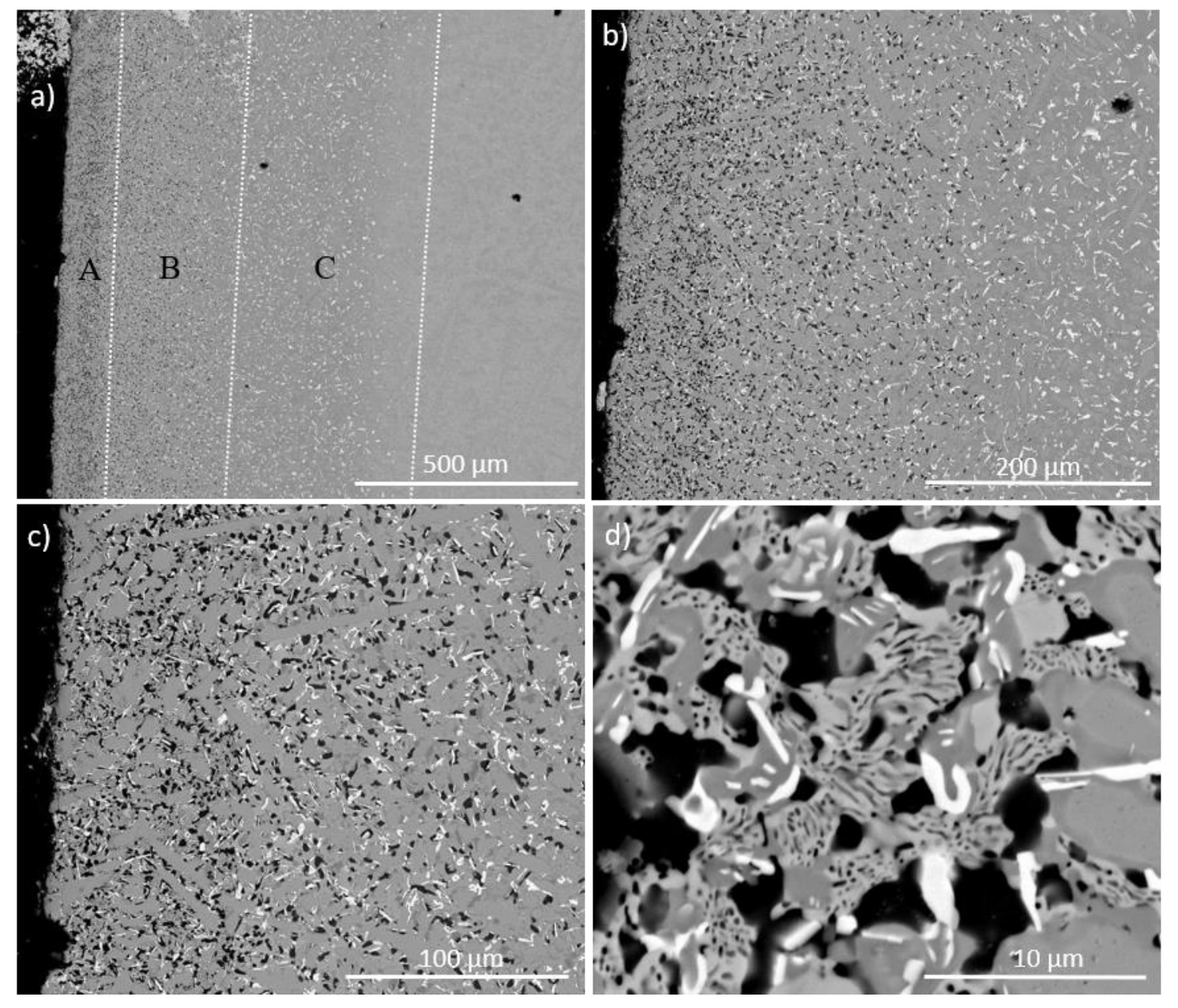

Figure 5. BSE images of cross section of the alloy NbSiTiHf-5Al-5Cr after isothermal oxidation at $1200{ }^{\circ} \mathrm{C}(\mathbf{a})$ showing overview of the sample and (b), (c) and (d) showing detail at greater magnification.

The chemical compositions of the phases in the bulk and the diffusion zone were analysed using WDS. The composition of $\mathrm{Nb}_{5} \mathrm{Si}_{3}$ was similar to that in the cast and heat treated alloy. Both the "normal" and Hf rich $\mathrm{Nb}_{5} \mathrm{Si}_{3}$ showed little affinity for oxygen, the maximum solubility of which was 0.7 at. $\% \mathrm{O}$. The $\mathrm{Nb}_{\mathrm{ss}}$ close to the surface was contaminated by oxygen and in the diffusion zone its oxygen content was 3.3 at.\% (Table S2 in Supplemental data). In the bulk of the sample, the $\mathrm{Nb}_{\mathrm{ss}} \mathrm{was}$ free of oxygen suggesting that the oxide formation at the surface and the scavenging of oxygen by $\mathrm{Hf}$ had stopped the oxygen ingress to the centre of the sample. The bright and black contrast regions (Figure 5) were analysed; the bright areas were $\mathrm{HfO}_{2}$ with a composition close to the stoichiometric ratio. The black precipitates were $\mathrm{TiO}_{2}$. Contamination of the $\mathrm{Nb}_{\mathrm{ss}}$ and $\mathrm{Nb}_{5} \mathrm{Si}_{3}$ was observed in the bulk of the alloy NbSiTiHf-5Al which was more severe compared with $800^{\circ} \mathrm{C}$. 


\subsection{Hardness and Young's Modulus}

In the bulk of the heat treated alloy NbSiTiHf-5Al-5Cr the average nano-hardness values of the $\mathrm{Nb}_{\mathrm{ss}}$ and $\mathrm{Nb}_{5} \mathrm{Si}_{3}$, respectively were $5.85 \mathrm{GPa}(597 \mathrm{HV})$ and $17.4 \mathrm{GPa}(1775 \mathrm{HV})$ and the Young's moduli, respectively were 137.6 GPa and 241.4 GPa (see Table 3).

Table 3. Hardness * and Young's moduli of $\mathrm{Nb}_{\mathrm{ss}}$ and $\mathrm{Nb}_{5} \mathrm{Si}_{3}$ in heat treated $\mathrm{Nb}$-silicide based alloys.

\begin{tabular}{|c|c|c|c|c|c|}
\hline Alloy & Phase & $\begin{array}{l}\text { Micro-Hardness } \\
\text { (Vickers) }\end{array}$ & $\begin{array}{l}\text { Nano-Hardness } \\
\text { (Vickers) }\end{array}$ & $\begin{array}{c}\text { Nano-Hardness } \\
\text { (GPa) }\end{array}$ & $\begin{array}{l}\text { Young's Modulus } \\
\text { (GPa) }\end{array}$ \\
\hline KZ7-HT & $\mathrm{Nb}_{\mathrm{SS}}$ & $395.0 \pm 19.0$ & $502.0 \pm 16.9$ & 4.95 & $138.0 \pm 12.0$ \\
\hline KZ5-HT & $\mathrm{Nb}_{\mathrm{SS}}$ & $466.0 \pm 20.0$ & $645.0 \pm 31.2$ & 6.5 & $131.0 \pm 18.0$ \\
\hline JN1-HT & $\mathrm{Nb}_{\mathrm{SS}}$ & $450.0 *$ & $597.0 \pm 35.8$ & 5.85 & $137.6 \pm 10.4$ \\
\hline KZ7-HT & $\alpha \mathrm{Nb}_{5} \mathrm{Si}_{3}$ & $1136.0 \pm 60.0$ & $1907.0 \pm 106.0$ & 18.7 & $283.8 \pm 25.2$ \\
\hline KZ5-HT & $\mathrm{Nb}_{5} \mathrm{Si}_{3}$ & $1131.0 \pm 54.0$ & $1685.0 \pm 142.0$ & 16.5 & $238.5 \pm 23.6$ \\
\hline JN1-HT & $\beta \mathrm{Nb}_{5} \mathrm{Si}_{3}$ & $1124.0 *$ & $1775.0 \pm 153.0$ & 17.4 & $241.4 \pm 24.7$ \\
\hline
\end{tabular}

\section{Discussion}

\subsection{Macrosegregation}

There was macrosegregation of $\mathrm{Si}(\mathrm{MACSi})$ and $\mathrm{Ti}(\mathrm{MACTi})$ in both alloys, which was more severe in the alloy NbSiTiHf-5Al. Furthermore, the chemical inhomogeneity of these elements persisted after the heat treatment.

The effects of individual and simultaneous additions of specific elements on the macrosegregation after casting and on the chemical inhomogeneity after heat treatment of $\mathrm{Si}$ and $\mathrm{Ti}$ in $\mathrm{Nb}$-silicide based alloys can be considered by comparing the data for different alloys. Figure 6 summarises the effects of $\mathrm{Al}, \mathrm{Cr}, \mathrm{Hf}$, or $\mathrm{Ti}$, and $\mathrm{Al}+\mathrm{Cr}, \mathrm{Al}+\mathrm{Hf}$, or $\mathrm{Al}+\mathrm{Ti}$ on the macrosegregation after casting and chemical inhomogeneity after heat treatment of $\mathrm{Si}$ and $\mathrm{Ti}$ in $\mathrm{Nb}$-silicide based alloys.

The nominal compositions of the alloys used for the comparisons are given below. When the effects of individual elements are considered, comparison of the alloys YG3 (=Nb-24Ti-18Si-5Hf [26]) and NbSiTiHf-5Al shows that $\mathrm{Al}$ increases MACSi and MACTi and that the chemical inhomogeneity of these elements persists after heat treatment. Similarly, comparison of the alloys NbSiTiHf-5Al and NbSiTiHf-5Al-5Cr shows that Cr decreases MACSi and MACTi, which is also supported by the data for the alloys KZ7 (=Nb-24Ti-18Si-5Al [25]) and KZ5 (=Nb-24Ti-18Si-5Al-5Cr [25]). The data for the alloys KZ5 and NbSiTiHf-5Al-5Cr, and KZ7 and NbSiTiHf-5Al show that Hf also increases MACSi and MACTi. Furthermore, comparison of the data for the alloys YG2 (=Nb-18Si-5Al-5Hf [26]) and NbSiTiHf-5Al shows that the addition of Ti increases MACSi.

Regarding the effects of two alloying additions simultaneously, (i) comparison of the alloys YG3 and NbSiTiHf-5Al-5Cr shows that $\mathrm{Al}+\mathrm{Cr}$ increase MACSi (Al eliminates the effect of $\mathrm{Cr}$ on MACSi) and decrease MACTi (Cr eliminates the effect of $\mathrm{Al}$ on MACTi), (ii) comparison of the alloys KZ4 (=Nb-24Ti-18Si-5Cr [25]) and NbSiTiHf-5Al-5Cr shows that Al+Hf increase MACSi and MACTi and that the synergy of these two elements reduces the effect of $\mathrm{Al}$, and finally (iii) comparison of the alloys YG1 (=Nb-18Si-5Cr-5Hf [26]) and NbSiTiHf-5Al-5Cr shows that Al+Ti increase MACSi (the synergy of these two elements reduces the effect of each element individually on MACSi) and MACTi.

The effect of the alloying additions of $\mathrm{Al}, \mathrm{Cr}, \mathrm{Hf}$, or Ti on the macrosegregation of $\mathrm{Si}$ can also be studied using the parameters discussed in [29]. The macrosegregation of Si increases from the alloy KZ5 (MACSi $=1.3$ at.\%) to KZ4 (1.9 at.\%) to KZ7 (2.3 at.\%) to YG2 (2.4 at.\%) to YG1 (2.5 at.\%) to YG3 (3.3 at.\%) to $\mathrm{NbSiTiHf}-5 \mathrm{Al}-5 \mathrm{Cr}$ (4 at.\%) to NbSiTiHf-5Al (7.4 at.\%) and this increase is accompanied by an increase of the parameters $\mathrm{T}_{\mathrm{m}}{ }^{\mathrm{sp}}, \Delta \mathrm{H}_{\mathrm{m}}{ }^{\mathrm{sp}}, \Delta \mathrm{H}_{\mathrm{m}}$ alloy $/ \mathrm{T}_{\mathrm{m}}$ alloy and a decrease of the parameter $\Delta \mathrm{H}_{\mathrm{m}}{ }^{\mathrm{sd}} / \Delta \mathrm{H}_{\mathrm{m}}{ }^{\mathrm{sp}}$ [29]. Details about the calculation of parameters are given in [29] but generally, $\mathrm{T}_{\mathrm{m}} \mathrm{sp}=\Sigma \mathrm{x}_{\mathrm{i}} \mathrm{T}_{\mathrm{mi}}{ }^{\mathrm{sp}}$ where $\mathrm{T}_{\mathrm{mi}}$ is melting temperature of sp element $\mathrm{i}$, and $\mathrm{x}_{\mathrm{i}}$ is at.\% of element $\mathrm{i} ; \Delta \mathrm{H}_{\mathrm{m}}{ }^{\mathrm{sp}}=\Sigma \mathrm{x}_{\mathrm{i}} \Delta \mathrm{H}_{\mathrm{mi}}{ }^{\text {sp }}$ where 
$\Delta \mathrm{H}_{\mathrm{mi}}$ is enthalpy of melting of sp element $\mathrm{i} ; \Delta \mathrm{H}_{\mathrm{m}}$ alloy $/ \mathrm{T}_{\mathrm{m}}$ alloy $=\Sigma \mathrm{x}_{\mathrm{i}} \Delta \mathrm{H}_{\mathrm{mi}}$ alloy $/ \Sigma \mathrm{x}_{\mathrm{i}} \mathrm{T}_{\mathrm{mi}}$ alloy or the 'alloy entropy of fusion', and $\Delta \mathrm{H}_{\mathrm{m}}{ }^{\text {sd }} / \Delta \mathrm{H}_{\mathrm{m}}{ }^{\text {sp }}=$ ratio of enthalpy of melting of sd elements to the sp elements. The synergy of $\mathrm{Al}, \mathrm{Cr}$, and $\mathrm{Ti}$ (alloy KZ5) gives the lowest MACSi and the latter increases when Hf is simultaneously present with the aforementioned elements (alloy NbSiTiHf-5Al-5Cr). The strongest effect on MACSi is from the synergy of $\mathrm{Al}, \mathrm{Hf}$, and Ti (alloy NbSiTiHf-5Al).

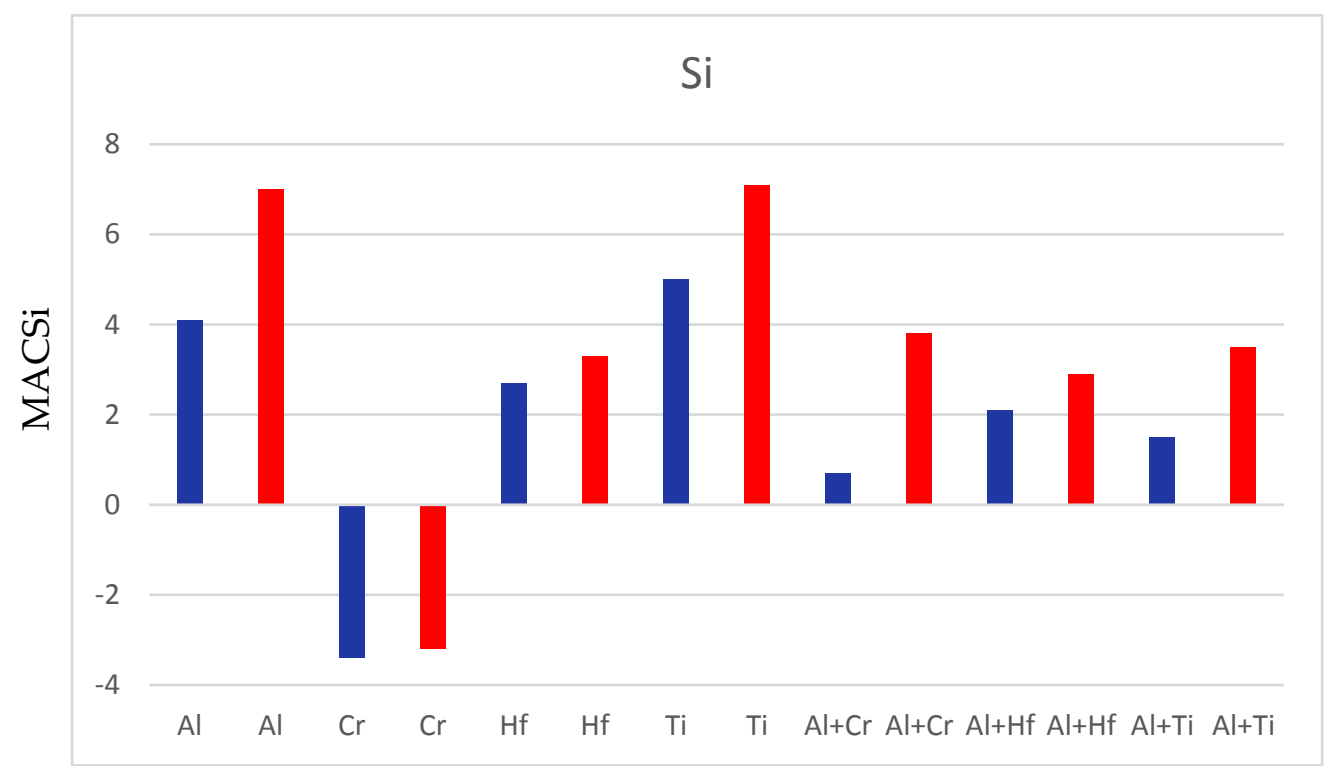

(a)

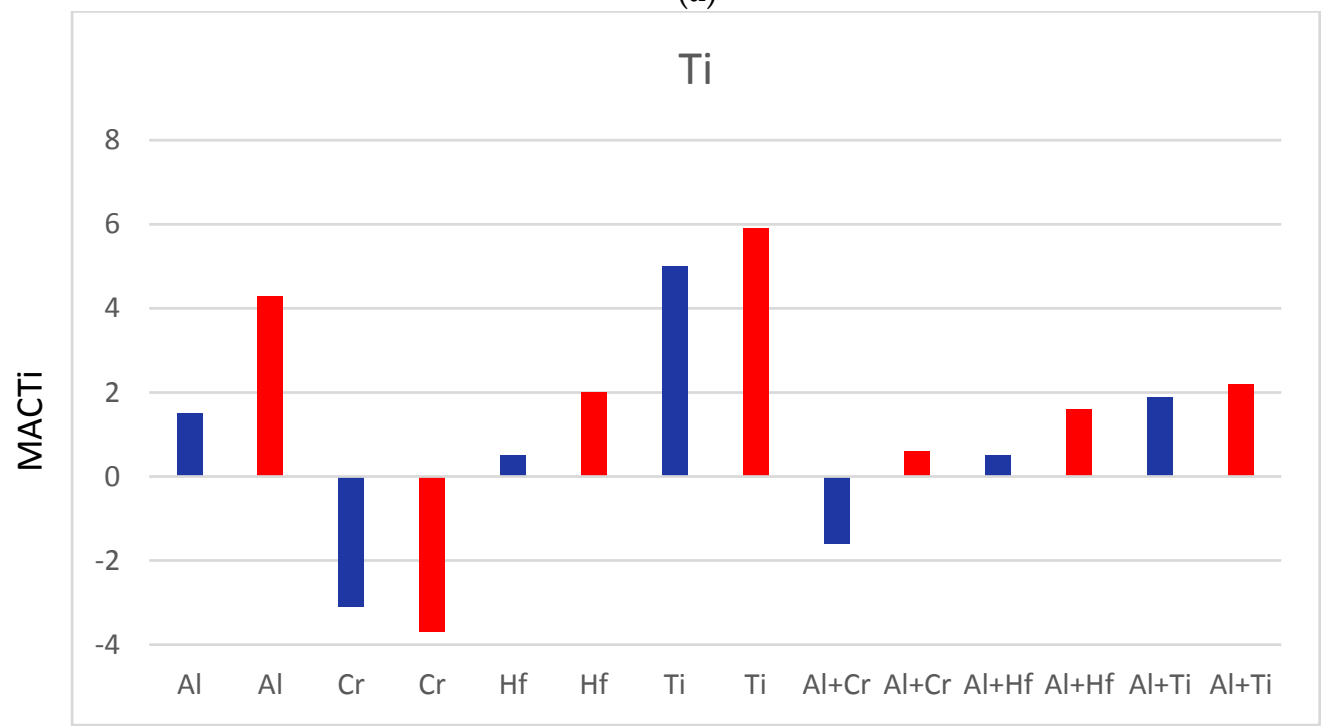

(b)

Figure 6. Effect of solute element(s) individually and in synergy on (ordinate) macrosegregation (at.\%) of $\mathrm{Si}$ and $\mathrm{Ti}$ in cast microstructures (blue colour) and chemical inhomogeneity (at.\%) of $\mathrm{Si}$ and $\mathrm{Ti}$ in heat treated microstructures (red colour). Data is shown as the difference from the values of the alloys NbSiTiHf-5Al and NbSiTiHf-5Al-5Cr, for example effect of $\mathrm{Al}$ on macrosegregation of $\mathrm{Si} \mathrm{MACSi}_{\mathrm{Al}}=$ $\mathrm{MACSi}^{\text {alloy NbSiTiHf-5Al }}-\mathrm{MACS}^{\text {alloy }}{ }^{\mathrm{YG} 3}=7.4-3.3=+4.1$ at. $\%$, and similarly $\mathrm{MACSi}_{\mathrm{Cr}}=\mathrm{MACS}^{\mathrm{allloy}}$ NbSiTiHf-5Al-5Cr - MACSialloy NbSiTiHf-5Al $=4-7.4=-3.4$ at.\%. Alloy YG3 $=$ Nb-18Si-5Hf-24Ti [26].

\subsection{Microstructure}

In the cast alloy $\mathrm{NbSiTiHf}-5 \mathrm{Al}$ there was $\mathrm{Hf}$ (and $\mathrm{Ti}$ ) rich $\mathrm{Nb}_{5} \mathrm{Si}_{3}$ in the very bottom of the button and in the "transition zone" from the bottom to the bulk, and "normal" $\mathrm{Nb}_{5} \mathrm{Si}_{3}$ in the latter and in 
the bulk and top of the button. Compared with the cast alloys KZ7 (=Nb-24Ti-18Si-5Al [25]) and YG3 (=Nb-24Ti-18Si-5Hf [26]), no Ti rich areas were observed in the $\mathrm{Nb}_{\mathrm{ss}}$ in NbSiTiHf-5Al. However, in contrast to the alloy NbSiTiHf-5Al, no Ti and $\mathrm{Hf}$ rich $\mathrm{Nb}_{5} \mathrm{Si}_{3}$ was observed in the alloy YG3. In the alloy NbSiTiHf-5Al (and also in the alloy NbSiTiHf-5Al-5Cr) the Hf (and Ti) rich $\mathrm{Nb}_{5} \mathrm{Si}_{3}$ formed as distinct grains as did the "normal" $\mathrm{Nb}_{5} \mathrm{Si}_{3}$. In the very bottom of the button of the alloy NbSiTiHf-5Al the $\mathrm{Nb}_{\mathrm{ss}}$ was leaner in $\mathrm{Hf}$ and Ti compared with the $\mathrm{Nb}_{\mathrm{ss}}$ in the bulk and top. The above discussion would suggest that cooling rate and melt composition (both $\mathrm{Hf}$ and $\mathrm{Al}$ were present in NbSiTiHf-5Al compared with the alloys KZ7 (no Hf) and YG3 (no Al)), influenced the partitioning of $\mathrm{Hf}$ and $\mathrm{Ti}$ between the melt, $\mathrm{Nb}_{5} \mathrm{Si}_{3}$, and $\mathrm{Nb}_{\mathrm{ss}}$. The presence of $\mathrm{\beta Nb}_{5} \mathrm{Si}_{3}$ and no $\alpha \mathrm{Nb}_{5} \mathrm{Si}_{3}$ in the cast alloy $\mathrm{NbSiTiHf}-5 \mathrm{Al}$ is consistent with the effect the addition of $\mathrm{Al}$ has on the type of primary $\mathrm{Nb}_{5} \mathrm{Si}_{3}$ formed in the cast microstructure [5]. Comparison with the cast alloy YG3 would suggest that the synergy of $\mathrm{Hf}$ with $\mathrm{Al}$ strengthened the effect of $\mathrm{Al}$, meaning it did not promote the $\beta \mathrm{Nb}_{5} \mathrm{Si}_{3} \rightarrow \alpha \mathrm{Nb}_{5} \mathrm{Si}_{3}$ transformation during solid state cooling.

The suppression of the $\mathrm{L} \rightarrow \mathrm{Nb}_{\mathrm{ss}}+\mathrm{Nb}_{3}$ Si eutectic is consistent with the absence of $\mathrm{Nb}_{3} \mathrm{Si}$ in the cast alloy NbSiTiHf-5Al, which is known to be suppressed by $\mathrm{Al}$ (see data for the alloy KZ7 in [25] and the alloy YG3 in [26], in the latter (no Al) the above eutectic was formed). The average $\mathrm{Si}+\mathrm{Al}$ composition $\left(\approx 20.6\right.$ at. $\%$ ) of the $\mathrm{Nb}_{\mathrm{ss}}+\mathrm{Nb}_{5} \mathrm{Si}_{3}$ eutectic was in agreement with [27].

As the $\mathrm{BNb}_{5} \mathrm{Si}_{3}$ formed in the very bottom of the button of the alloy NbSiTiHf-5Al, the surrounding melt became lean in $\mathrm{Si}$ and $\mathrm{Hf}$ and rich in $\mathrm{Ti}$ and $\mathrm{Al}$. In this melt, $\mathrm{Nb}_{\mathrm{ss}}$ formed and the melt became rich in $\mathrm{Si}$ and $\mathrm{Hf}$ and poor in $\mathrm{Al}$, and its Ti concentration did not change. As the cooling rate decreased, in the latter melt "normal" $\beta \mathrm{Nb}_{5} \mathrm{Si}_{3}$ formed, the surrounding melt became lean in $\mathrm{Si}$ and $\mathrm{Ti}$, and $\mathrm{Hf}$ had more time to partition to the melt, which thus became richer in $\mathrm{Al}, \mathrm{Hf}$, and Ti. From this melt $\mathrm{Nb}_{\mathrm{ss}}$ - slightly richer in Ti and $\mathrm{Hf}$ compared with the $\mathrm{Nb}_{\mathrm{ss}}$ - formed in the bottom of the button and as this $\mathrm{Nb}_{\mathrm{ss}}$ formed the melt became rich in $\mathrm{Si}, \mathrm{Hf}$ and poor in $\mathrm{Al}$. When the $\mathrm{Si}+\mathrm{Al}$ composition of the melt approached that of the $\mathrm{Nb}_{\mathrm{ss}}+\mathrm{Nb}_{5} \mathrm{Si}_{3}$ eutectic the latter formed either in-between $\mathrm{Nb}_{\mathrm{ss}}$ grains or from the $\mathrm{Nb}_{\mathrm{ss}}$ that was formed on $\mathrm{Nb}_{5} \mathrm{Si}_{3}$ grains. Thus, from the observed microstructure in the cast alloy NbSiTiHf-5Al it is suggested that the solidification path in the bulk of the alloy NbSiTiHf-5Al was $\mathrm{L} \rightarrow \mathrm{L}+\beta \mathrm{Nb}_{5} \mathrm{Si}_{3} \rightarrow \mathrm{L}+\beta \mathrm{Nb}_{5} \mathrm{Si}_{3}+\mathrm{Nb}_{\mathrm{ss}} \rightarrow \beta \mathrm{Nb}_{5} \mathrm{Si}_{3}+\mathrm{Nb}_{\mathrm{ss}}+\left(\beta \mathrm{Nb}_{5} \mathrm{Si}_{3}+\mathrm{Nb}_{\text {ss }}\right)_{\text {eutectic }}$ with hexagonal $\gamma \mathrm{Nb}_{5} \mathrm{Si}_{3}$ forming in the early stages of solidification (i.e., near the water cooled copper crucible), owing to the partitioning of $\mathrm{Hf}$ and Ti.

The formation of $\mathrm{C} 14-\mathrm{NbCr}_{2}$ in $\mathrm{Nb}$-silicide alloys is linked with the partitioning of $\mathrm{Cr}$ to the melt which, as the solidification progresses, becomes rich in $\mathrm{Cr}$ and the Laves forms from the last to solidify Cr-rich melt [25]. In the cast alloy NbSiTiHf-5Al-5Cr the partitioning of $\mathrm{Hf}$ in the $\mathrm{Nb}_{\mathrm{ss}}$ and $\beta_{N_{5}} \mathrm{Si}_{3}$ and the corresponding increase in the concentration of $\mathrm{Cr}$ (and Ti) in the Hf (and Ti) rich $\mathrm{Nb}_{\mathrm{ss}}$ starved the inter-dendritic melt from the high $\mathrm{Cr}$ concentration that would have promoted the formation of $\mathrm{C} 14-\mathrm{NbCr}_{2}$. Areas in the microstructure of the cast alloy NbSiTiHf-5Al-5Cr where Laves phase could form were much too small to analyse using EDS/WDS. The X-ray maps (Figure 1) were non-conclusive regarding the presence of the Laves phase. If the Laves phase was present in the alloy NbSiTiHf-5Al-5Cr, it is not likely that it had formed at a high volume fraction.

The C14- $\mathrm{NbCr}_{2}$ Laves phase was formed in the cast alloy KZ5 (=Nb-24Ti-18Si-5Cr [25]). Another reason for the stabilisation of the $\mathrm{C} 14-\mathrm{NbCr}_{2}$ Laves phase in the cast alloy $\mathrm{KZ} 5$ and not in the alloy NbSiTiHf-5Al-5Cr would be the higher actual Cr concentration in $\mathrm{KZ}$, which was 6.8 to 7.6 at.\% [25].

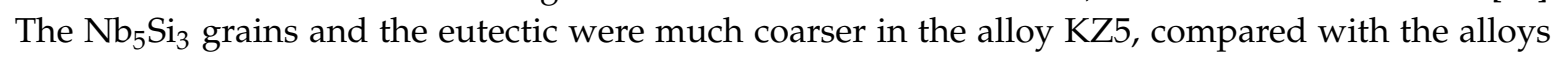
$\mathrm{NbSiTiHf}-5 \mathrm{Al}$ and $\mathrm{NbSiTiHf}-5 \mathrm{Al}-5 \mathrm{Cr}$; this would suggest a refining effect of $\mathrm{Hf}$ on the microstructure and is in agreement with [32].

From the observed microstructure in the cast alloy JN1, the following solidification path is suggested: $\mathrm{L} \rightarrow \mathrm{L}+\beta \mathrm{Nb}_{5} \mathrm{Si}_{3} \rightarrow \mathrm{L}+\beta \mathrm{Nb}_{5} \mathrm{Si}_{3}+\mathrm{Nb}_{\mathrm{ss}} \rightarrow \beta \mathrm{Nb}_{5} \mathrm{Si}_{3}+\mathrm{Nb}_{\mathrm{ss}}+\left(\beta \mathrm{Nb}_{5} \mathrm{Si}_{3}+\mathrm{Nb}_{\mathrm{ss}}\right)_{\text {eutectic }}$. Regarding the structure of $\mathrm{Nb}_{5} \mathrm{Si}_{3}$, the XRD data for the cast alloy NbSiTiHf-5Al-5Cr confirmed only the presence of tetragonal $\beta \mathrm{Nb}_{5} \mathrm{Si}_{3}$. The volume fractions were 0.42 and 0.58 , respectively for the $\mathrm{Nb}_{\mathrm{ss}}$ and the $\beta \mathrm{Nb}_{5} \mathrm{Si}_{3}$. 
The bcc $\mathrm{Nb}$ solid solution was stable in both the alloys NbSiTiHf-5Al and NbSiTiHf-5Al-5Cr and in the latter it also formed Hf rich regions, which were not observed after the heat treatment. Hafnium and Ti partition to the $\mathrm{Nb}_{\mathrm{ss}}$ where the increase in the concentration of one of these elements is accompanied by an increase in the concentration of the other. In other words, "Ti and Hf like each other in the solid solution". Thus, the Hf rich $\mathrm{Nb}_{\mathrm{ss}}$ in the alloy NbSiTiHf-5Al-5Cr was also Ti rich compared with the "normal" $\mathrm{Nb}_{\mathrm{ss}}$. Comparison of the data for the alloys YG3 (=Nb-24Ti-18Si-5Hf [26]) and NbSiTiHf-5Al shows that the synergy of $\mathrm{Al}$ with $\mathrm{Hf}$ in the latter alloy decreased the partitioning of $\mathrm{Ti}$ in the $\mathrm{Nb}_{\mathrm{ss}}$ (Ti-rich $\mathrm{Nb}_{\mathrm{ss}}$ was observed only in the cast alloy YG3). The increase of the $\mathrm{Cr}$ and $\mathrm{Hf}$ concentrations in the $\mathrm{Hf}$ rich $\mathrm{Nb}_{\mathrm{ss}}$ in the alloy $\mathrm{NbSiTiHf}-5 \mathrm{Al}-5 \mathrm{Cr}$ was in agreement with the dependence of the concentrations of these elements on the Ti concentration in the $\mathrm{Nb}_{\mathrm{ss}}$.

The parameters VEC (valence electron concentration), $\delta$ (related to atomic size), and $\Delta \chi$ (related to electronegativity) can describe the alloying behaviour of the bcc $\mathrm{Nb}_{\mathrm{ss}}$ [33]. The effects of alloying additions individually and simultaneously in $\mathrm{Nb}$-silicide based alloys on the alloying behaviour of their $\mathrm{Nb}$ solid solutions can be determined by comparing data for different alloys. For example, comparison of the alloys YG3 and NbSiTiHf-5Al shows that Al decreases VEC, and comparison of the alloys YG2 (=Nb-18Si-5Hf-5Al [26]) and NbSiTiHf-5Al shows that Ti decreases VEC, and increases $\delta$ and $\Delta x$. The data is summarised in Figure 7, which shows the effects of $\mathrm{Al}, \mathrm{Cr}, \mathrm{Hf}$, or $\mathrm{Ti}$, and $\mathrm{Al}+\mathrm{Cr}$, $\mathrm{Al}+\mathrm{Hf}$, or $\mathrm{Al}+\mathrm{Ti}$ on the parameters $\mathrm{VEC}, \delta$, and $\Delta \chi$. The latter parameters were calculated as described in [33]. It should be noted that these three parameters are key for the design of $\mathrm{Nb}$-silicide based alloys and their solid solutions, and also are linked with their oxidation and creep properties, see [2].

The $\mathrm{Al}, \mathrm{Hf}$, and Ti concentrations in the $\mathrm{Nb}_{5} \mathrm{Si}_{3}$ silicide are indicated in Figure 8, which shows the trends of the $\mathrm{Si}$ versus $\mathrm{Ti}$, $\mathrm{Al}$ versus $\mathrm{Ti}$, and $\mathrm{Hf}$ versus $\mathrm{Nb}$ concentrations in $\mathrm{Nb}_{5} \mathrm{Si}_{3}$ in $\mathrm{Nb}$-silicide based alloys studied in our research group, see [34]. The alloying elements in each sub-set of data are given in the figure caption. The data in Figures 1 and 8 in [34] show that there exist strong correlations between solute elements in $\mathrm{Nb}_{5} \mathrm{Si}_{3}$. The data points for the $\mathrm{Nb}_{5} \mathrm{Si}_{3}$ in the alloys NbSiTiHf-5Al and $\mathrm{NbSiTiHf}-5 \mathrm{Al}-5 \mathrm{Cr}$ fall on the trends that have been found in our research group (for example see $[5,25,34])$. Figure 8 a shows that the $\mathrm{Si}$ concentration in $\mathrm{Nb}_{5} \mathrm{Si}_{3}$ decreases with increasing $\mathrm{Ti}$ concentration. The $\mathrm{Al}$ concentration in $\mathrm{Nb}_{5} \mathrm{Si}_{3}$ exhibits the opposite trend with increasing Ti content (Figure 8b). The concentration of $\mathrm{Hf}$ in $\mathrm{Nb}_{5} \mathrm{Si}_{3}$ also increases with the Ti concentration (the data for $\mathrm{Hf}$ versus $\mathrm{Ti}$ in $\mathrm{Hf}$ rich and "normal" $\mathrm{Nb}_{5} \mathrm{Si}_{3}$ gives $\mathrm{R}^{2}=0.77$, figure not shown). Interestingly, the $\mathrm{Hf}$ concentration in the $\mathrm{Nb}_{5} \mathrm{Si}_{3}$ is also related with that of $\mathrm{Nb}$, as shown in [34]. In Figure $8 \mathrm{c}$ the best linear fit of the data excluding the alloys NbSiTiHf-5Al-5Cr and NbSiTiHf-5Al gives $\mathrm{R}^{2}=0.952$.

The relationships between the $\mathrm{Al}$ and $\mathrm{Ti}$, or $\mathrm{Cr}$ and Ti concentrations in the $\mathrm{Nb}_{\mathrm{ss}}$ in cast and heat treated KZ series alloys [25] are shown in Figure 9. It is seen that the concentrations of $\mathrm{Al}$ and $\mathrm{Cr}$ in the $\mathrm{Nb}_{\mathrm{ss}}$ increase with its Ti concentration. The data for $\mathrm{Al}$ in the cast and heat treated alloys NbSiTiHf-5Al and NbSiTiHf-5Al-5Cr and for $\mathrm{Cr}$ in the heat treated alloy NbSiTiHf-5Al-5Cr falls on or is very close to the best linear fit lines in Figure 9.

The microstructure of the heat treated alloy NbSiTiHf-5Al consisted of $\beta \mathrm{Nb}_{5} \mathrm{Si}_{3}$ and $\gamma \mathrm{Nb}_{5} \mathrm{Si}_{3}, \mathrm{Nb}_{\mathrm{ss}}$, and coarsened prior eutectic. Comparison with the heat treated alloys KZ7 (=Nb-24Ti-18Si-5Al [25]) and YG3 (=Nb-24Ti-18Si-5Hf [26]) would suggest (i) that the addition of $\mathrm{Hf}$ stabilised the $\mathrm{\beta Nb}_{5} \mathrm{Si}_{3}$ and (ii) that the synergy of $\mathrm{Al}$ with $\mathrm{Hf}$ and Ti promoted the stability of $\gamma \mathrm{Nb}_{5} \mathrm{Si}_{3}$. $\mathrm{No} \mathrm{Nb}_{\text {ss }}$ precipitates were observed in the $\mathrm{Nb}_{5} \mathrm{Si}_{3}$ in the heat treated alloys NbSiTiHf-5Al and NbSiTiHf-5Al-5Cr, which is consistent with the precipitation of $\mathrm{Nb}_{\mathrm{ss}}$ often observed in $\alpha \mathrm{Nb}_{5} \mathrm{Si}_{3}$ as part of the $\beta \mathrm{Nb}_{5} \mathrm{Si}_{3}$ to $\alpha \mathrm{Nb}_{5} \mathrm{Si}_{3}$ transformation in $\mathrm{Nb}$ silicide based alloys [25]. The presence of coarsened prior eutectic in the alloy NbSiTiHf-5Al compared with its absence in the alloys KZ7 and YG3 can be explained by the lower homologous heat treatment temperature. 


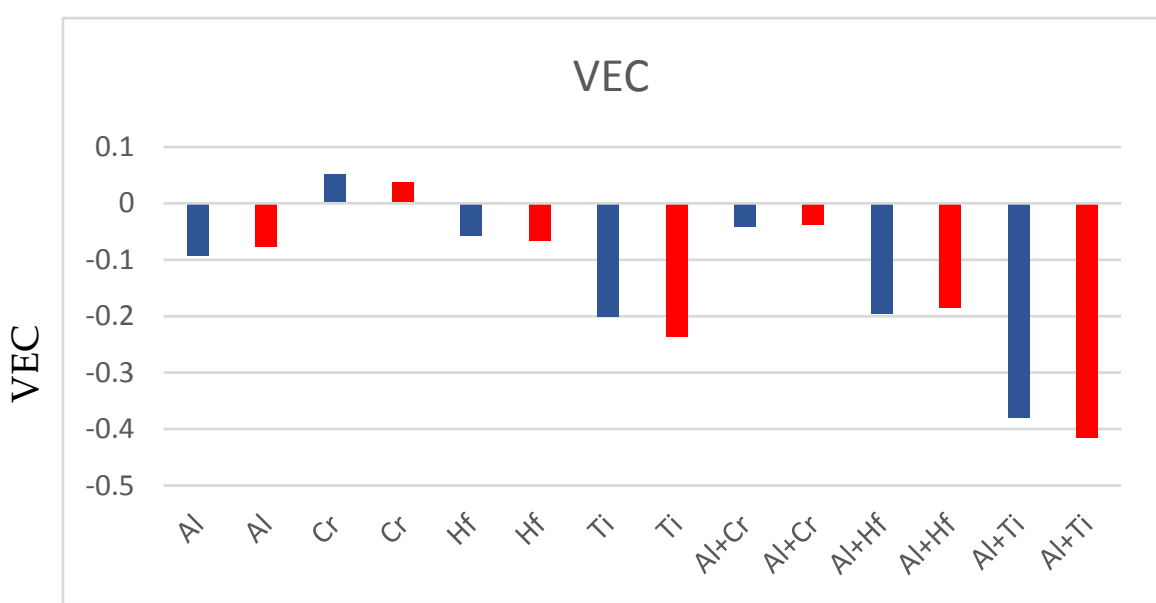

(a)

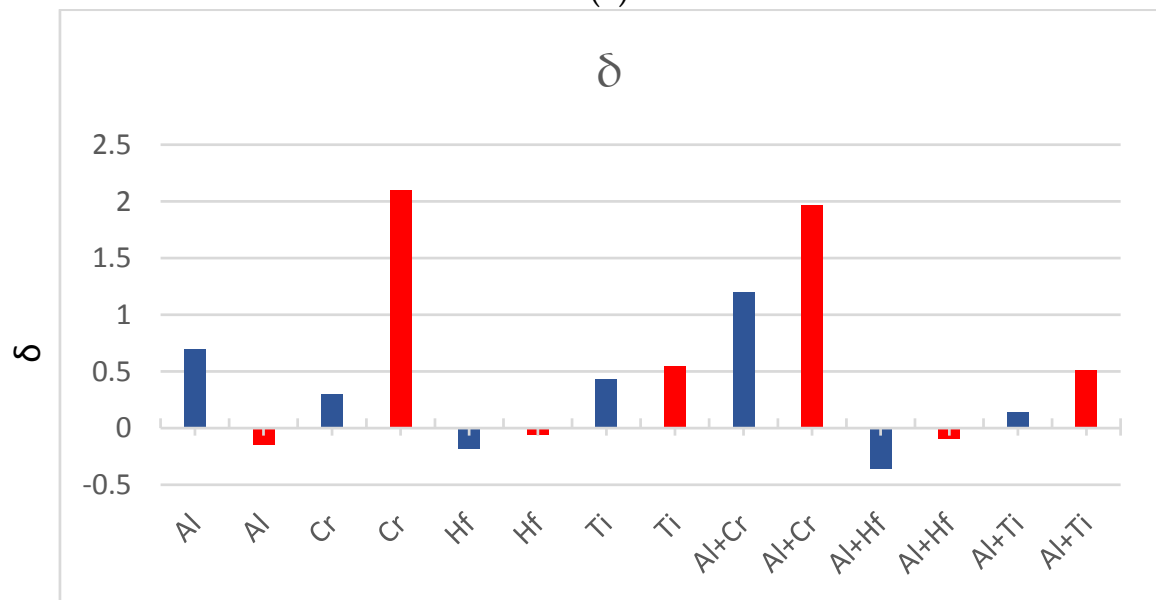

(b)

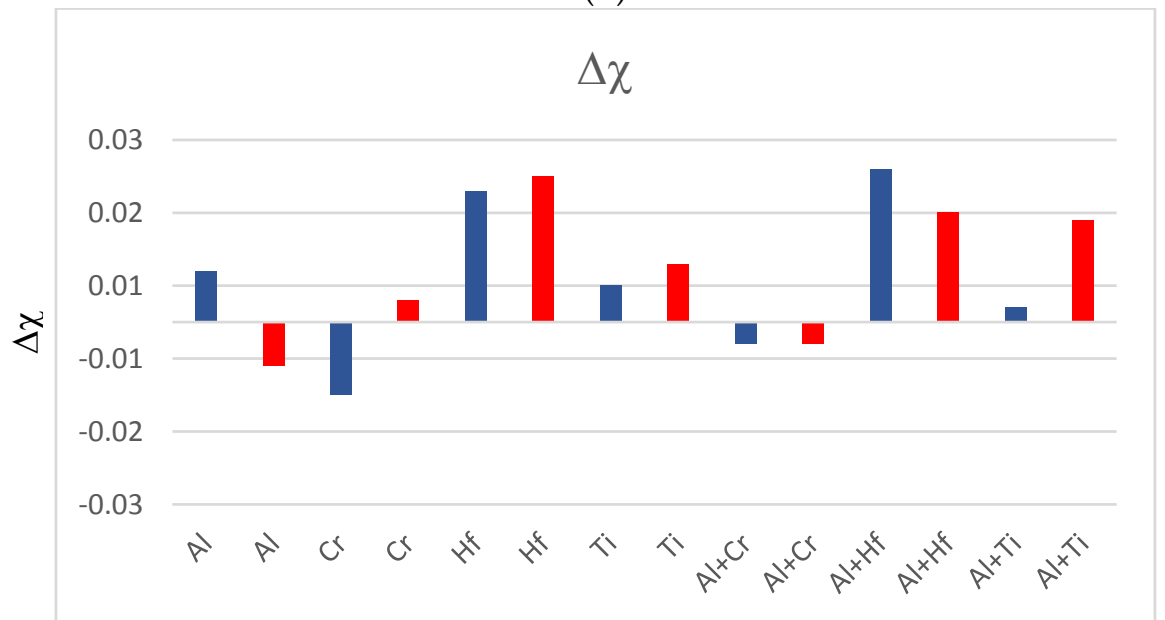

(c)

Figure 7. Effect of solute element(s) individually and in synergy on the parameters (ordinate) VEC, $\delta$ and $\Delta x$ of the $\mathrm{Nb}_{\mathrm{ss}}$ in cast microstructures (blue colour) and in heat treated microstructures (red colour). Data is shown as the difference from the values of the alloys NbSiTiHf-5Al and $\mathrm{NbSiTiHf}-5 \mathrm{Al}-5 \mathrm{Cr}$, for example, the effect of $\mathrm{Al}$ on the parameter $\mathrm{VEC}$ is $\mathrm{VEC}_{\mathrm{Al}}=\mathrm{VEC}^{\mathrm{Nbss}} \mathrm{NbSiTiHf}-5 \mathrm{Al}$ - VEC $^{\text {Nbss YG3 }}=4.586-4.679=-0.093$, similarly $\delta_{\mathrm{Al}}=\delta^{\mathrm{Nbss} N \text { NbiTiHf-5Al }}-\delta^{\mathrm{Nbss} Y G 3}=4.34-3.64=$ +0.7 . The nominal composition of the alloy YG3 is Nb-24Ti-18Si-5Hf [26]. 


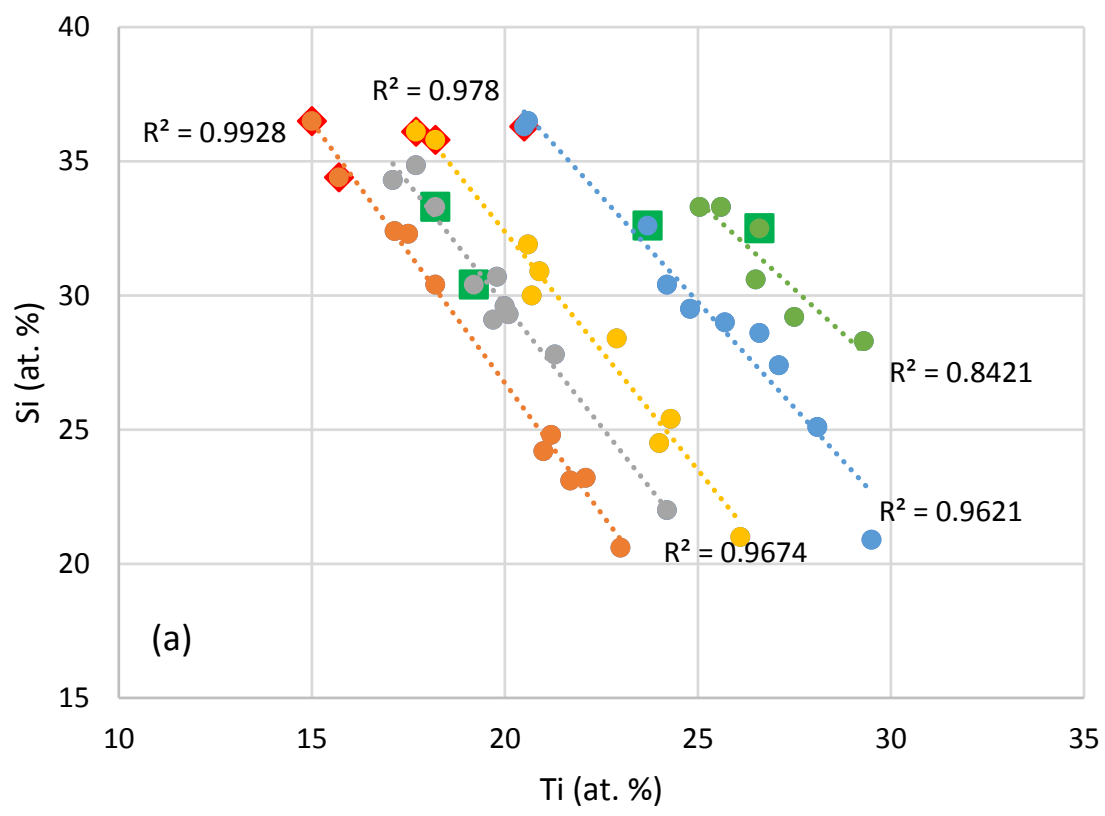

(a)

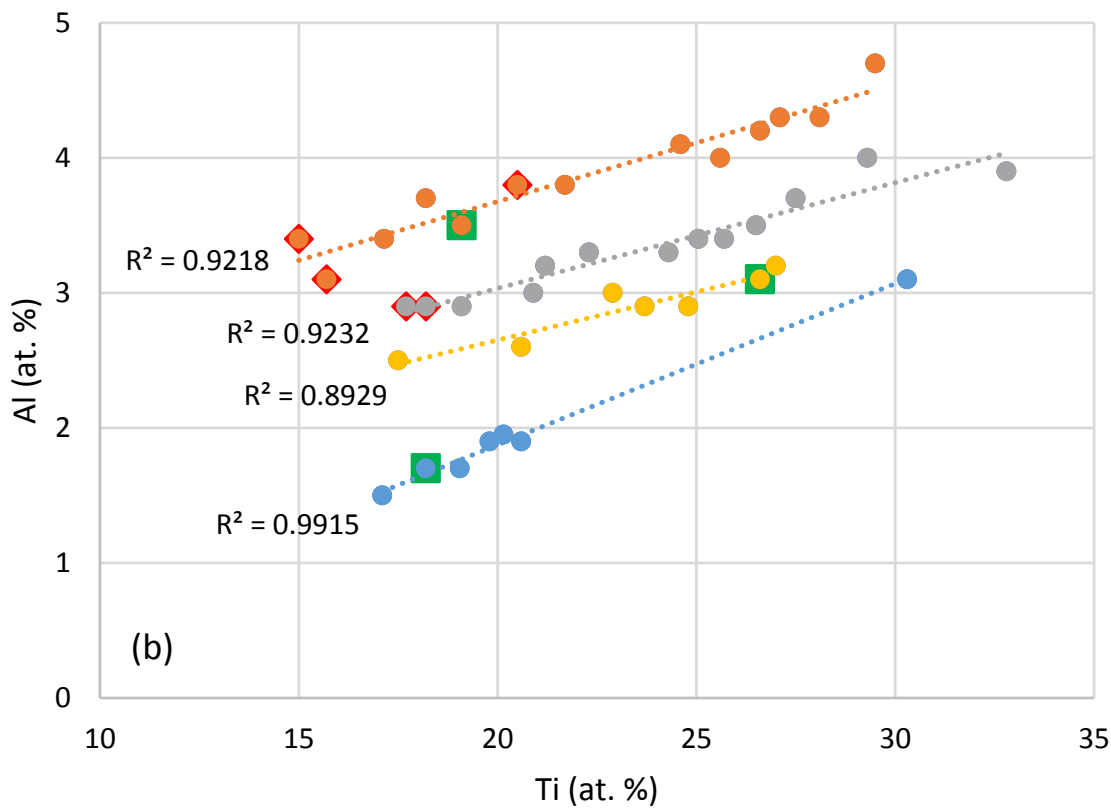

(b)

Figure 8. Cont. 


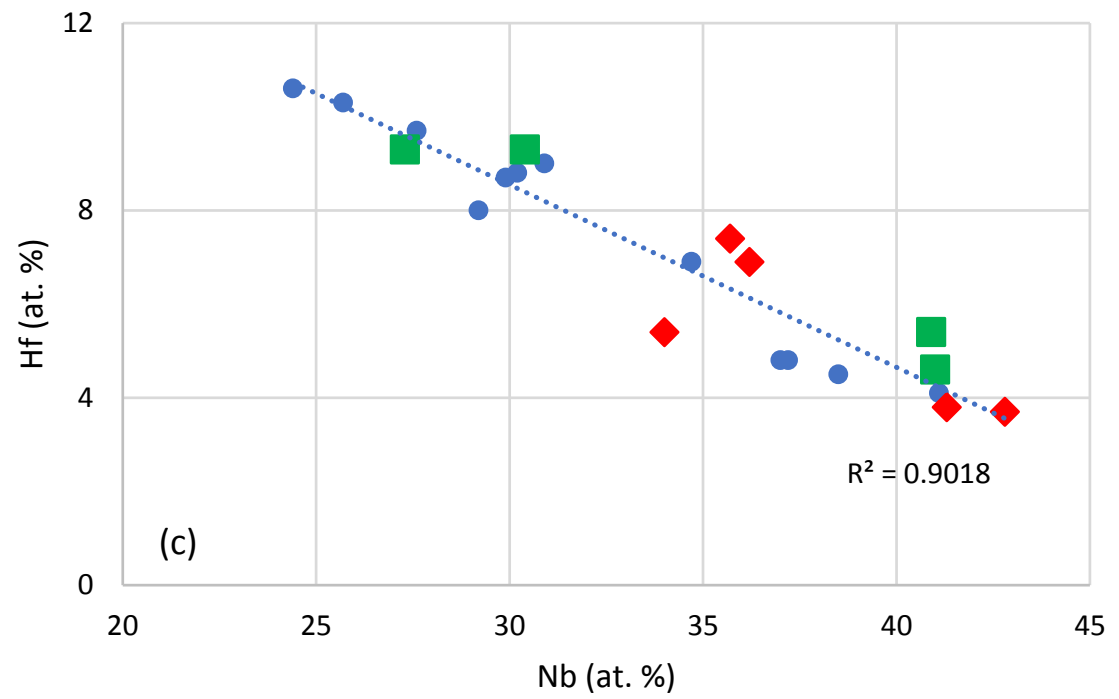

(c)

Figure 8. (a) $\mathrm{Si}$ versus $\mathrm{Ti}$ in $\mathrm{Nb}_{5} \mathrm{Si}_{3}$, (b) $\mathrm{Al}$ versus $\mathrm{Ti}$ in $\mathrm{Nb}_{5} \mathrm{Si}_{3}$, (c) $\mathrm{Hf}$ versus $\mathrm{Nb}$ in $\mathrm{Nb}_{5} \mathrm{Si}_{3}$. Squares and diamonds show data for the alloys NbSiTiHf-5Al-5Cr and NbSiTiHf-5Al, respectively. The data is for $\mathrm{Nb}_{5} \mathrm{Si}_{3}$ silicides in alloys studied in our research group (see [34] and [5,25]). In (a) series a $\left(R^{2}=0.9928\right)$ with alloying element additions of $\mathrm{Al}, \mathrm{Cr}, \mathrm{Ge}, \mathrm{Hf}, \mathrm{Si}, \mathrm{Sn}$, Ti; series b $\left(\mathrm{R}^{2}=0.9674\right) \mathrm{Al}, \mathrm{B}, \mathrm{Cr}, \mathrm{Ge}, \mathrm{Hf}, \mathrm{Mo}$, $\mathrm{Si}$, Sn, Ta, Ti; series c ( $\left.\mathrm{R}^{2}=0.978\right) \mathrm{Al}, \mathrm{B}, \mathrm{Cr}, \mathrm{Ge}, \mathrm{Hf}, \mathrm{Si}, \mathrm{Sn}, \mathrm{Ta}$, Ti; series d $\left(\mathrm{R}^{2}=0.9621\right) \mathrm{Al}, \mathrm{B}, \mathrm{Cr}, \mathrm{Ge}, \mathrm{Hf}$, $\mathrm{Mo}, \mathrm{Si}, \mathrm{Ta}$, Ti; and series e $\left(\mathrm{R}^{2}=0.8421\right) \mathrm{Al}, \mathrm{B}, \mathrm{Cr}, \mathrm{Hf}, \mathrm{Mo}, \mathrm{Si}, \mathrm{Sn}$, Ta, Ti. In $(\mathbf{b})$ series a $\left(\mathrm{R}^{2}=0.9218\right)$ with alloying element additions $\mathrm{Al}, \mathrm{B}, \mathrm{Cr}, \mathrm{Ge}, \mathrm{Hf}, \mathrm{Si}$, Sn, Ti; series b $\left(\mathrm{R}^{2}=0.9232\right) \mathrm{Al}, \mathrm{B}, \mathrm{Cr}, \mathrm{Ge}, \mathrm{Mo}, \mathrm{Si}, \mathrm{Sn}, \mathrm{Ta}$, Ti; series c $\left(R^{2}=0.8929\right) \mathrm{Al}, \mathrm{B}, \mathrm{Cr}, \mathrm{Hf}, \mathrm{Si}, \mathrm{Sn}, \mathrm{Ti}$; and series d $\left(\mathrm{R}^{2}=0.9915\right) \mathrm{Al}, \mathrm{B}, \mathrm{Cr}, \mathrm{Mo}, \mathrm{Si}, \mathrm{Sn}, \mathrm{Ta}, \mathrm{Ti}$. In (c) blue data points are for $\mathrm{Nb}_{5} \mathrm{Si}_{3}$ silicides with alloying element additions of $\mathrm{Al}, \mathrm{B}, \mathrm{Cr}, \mathrm{Ge}, \mathrm{Hf}, \mathrm{Si}$, Sn, Ti.

The current thermodynamic databases cannot account for the presence of bcc $\mathrm{Nb}_{\mathrm{ss}}, \mathrm{NNb}_{5} \mathrm{Si}_{3}$, and hexagonal $\gamma \mathrm{Nb}_{5} \mathrm{Si}_{3}$ in the heat treated alloy NbSiTiHf-5Al. The alloy NbSiTiHf-5Al was heat treated at $1300{ }^{\circ} \mathrm{C}$ for $100 \mathrm{~h}$, and it cannot be inferred that equilibrium was reached in its microstructure. In the alloy KZ7 (no Hf) the transformation $\beta \mathrm{Nb}_{5} \mathrm{Si}_{3} \rightarrow \alpha \mathrm{Nb}_{5} \mathrm{Si}_{3}$ was completed after the $100 \mathrm{~h}$ heat treatment at $1500{ }^{\circ} \mathrm{C}$. Thus, it is possible either that in the alloy NbSiTiHf-5Al the above transformation had not progressed enough (because of the lower heat treatment temperature) to give a volume fraction of $\alpha \mathrm{Nb}_{5} \mathrm{Si}_{3}$ that could be detected by XRD, or that the synergy of $\mathrm{Hf}$ and $\mathrm{Al}$ suppressed the above transformation. The latter is supported by the results for the heat treated $\left(1500^{\circ} \mathrm{C} / 100 \mathrm{~h}\right)$ alloy NbSiTiHf-5Al-5Cr where the $\beta \mathrm{Nb5Si3}$ was still present, while in the heat treated $\left(1500{ }^{\circ} \mathrm{C} / 100 \mathrm{~h}\right)$ alloy $\mathrm{KZ5}$ (=Nb-24Ti-18Si-5Al-5Cr [25]) both the $\beta \mathrm{Nb}_{5} \mathrm{Si}_{3}$ and $\alpha \mathrm{Nb}_{5} \mathrm{Si}_{3}$ were present [25], and in both alloys (i.e., NbSiTiHf-5Al-5Cr and KZ5) the solubility of $\mathrm{Cr}$ in the $\mathrm{Nb}_{5} \mathrm{Si}_{3}$ was very low $\left(\mathrm{Cr}_{5} \mathrm{Si}_{3}\right.$ and $\beta \mathrm{Nb}_{5} \mathrm{Si}_{3}$ have $\mathrm{W}_{5} \mathrm{Si}_{3}$ as prototype and one would expect $\mathrm{Cr}$ in synergy with $\mathrm{Al}$ to stabilise the $\beta \mathrm{Nb}_{5} \mathrm{Si}_{3}$ ). If we were to consider $\mathrm{Nb}, \mathrm{Hf}$, and Ti as equivalent in this alloy then the NbSiTiHf- $5 \mathrm{Al}$ is in the $\mathrm{Nb}_{\mathrm{ss}}+$ $\alpha \mathrm{Nb}_{5} \mathrm{Si}_{3}$ two phase area in the isothermal $\mathrm{Nb}$-Si-Al sections at $1400{ }^{\circ} \mathrm{C}$ in [35] and $1300{ }^{\circ} \mathrm{C}$ in [36], and in the isothermal Ti-Al-Si sections at $1200{ }^{\circ} \mathrm{C}$ in [37] and $1270{ }^{\circ} \mathrm{C}$ in [38] the alloy falls in the bcc $\mathrm{Ti}_{\mathrm{ss}}$ and $\mathrm{Ti}_{5} \mathrm{Si}_{3}$ two phase area. The latter would suggest that $\mathrm{Hf}$ and $\mathrm{Ti}$, which form hexagonal $\mathrm{Hf}_{5} \mathrm{Si}_{3}$ and $\mathrm{Ti}_{5} \mathrm{Si}_{3}$ compounds with the same structure as the hexagonal $\gamma \mathrm{Nb}_{5} \mathrm{Si}_{3}$, promoted the stability of $\gamma \mathrm{Nb}_{5} \mathrm{Si}_{3}$ in the alloy NbSiTiHf-5Al. Therefore, the suppression of the $\beta \mathrm{Nb}_{5} \mathrm{Si}_{3}$ to $\alpha \mathrm{Nb}_{5} \mathrm{Si}_{3}$ transformation in this alloy could be linked with the stability of the $\gamma \mathrm{Nb}_{5} \mathrm{Si}_{3}$. The latter would suggest that after prolonged heat treatment the $\gamma \mathrm{Nb}_{5} \mathrm{Si}_{3}$ could be stable in the alloy NbSiTiHf-5Al-5Cr. It should be noted that Hf rich $\mathrm{Nb}_{\mathrm{ss}}$ was formed in the cast alloy NbSiTiHf-5Al-5Cr but not in the cast alloy NbSiTiHf-5Al, and 
therefore less $\mathrm{Hf}$ was available in the former alloy to partition to $\mathrm{Nb}_{5} \mathrm{Si}_{3}$. The diffusion distance of $\mathrm{Hf}$ in $\mathrm{Nb}$ is $\approx 18 \mu \mathrm{m}$ and $31 \mu \mathrm{m}$, respectively after 100 and $300 \mathrm{~h}$ at $1500{ }^{\circ} \mathrm{C}$.

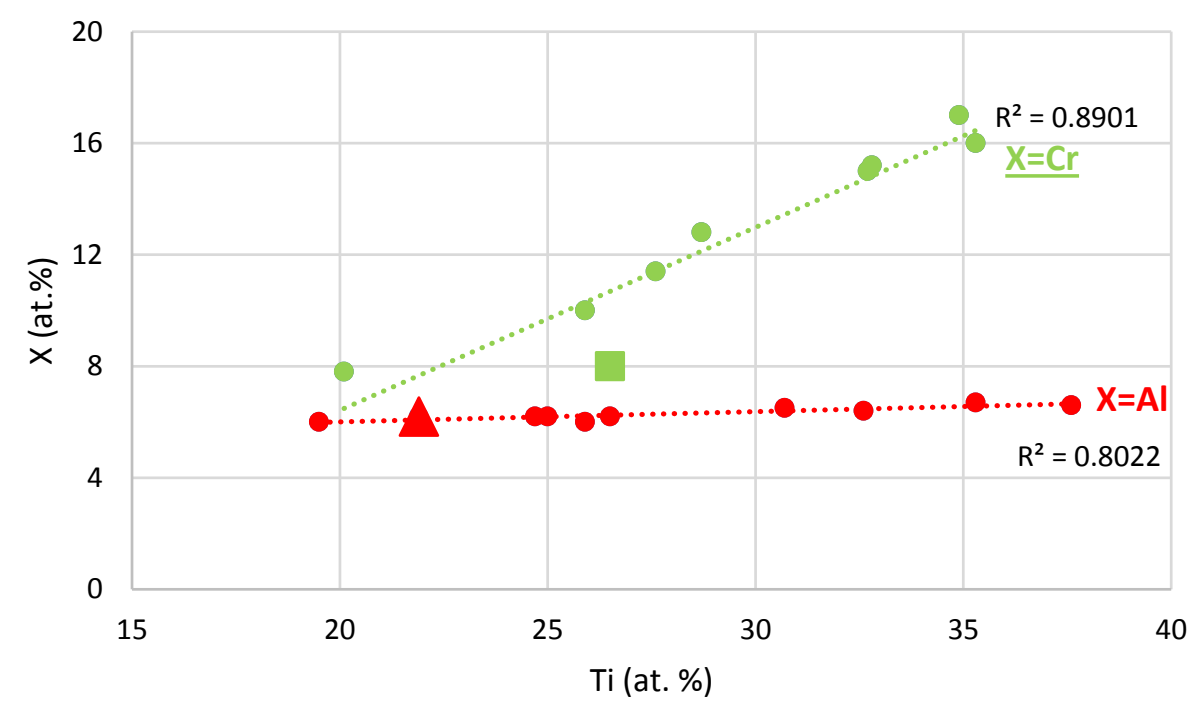

(a)

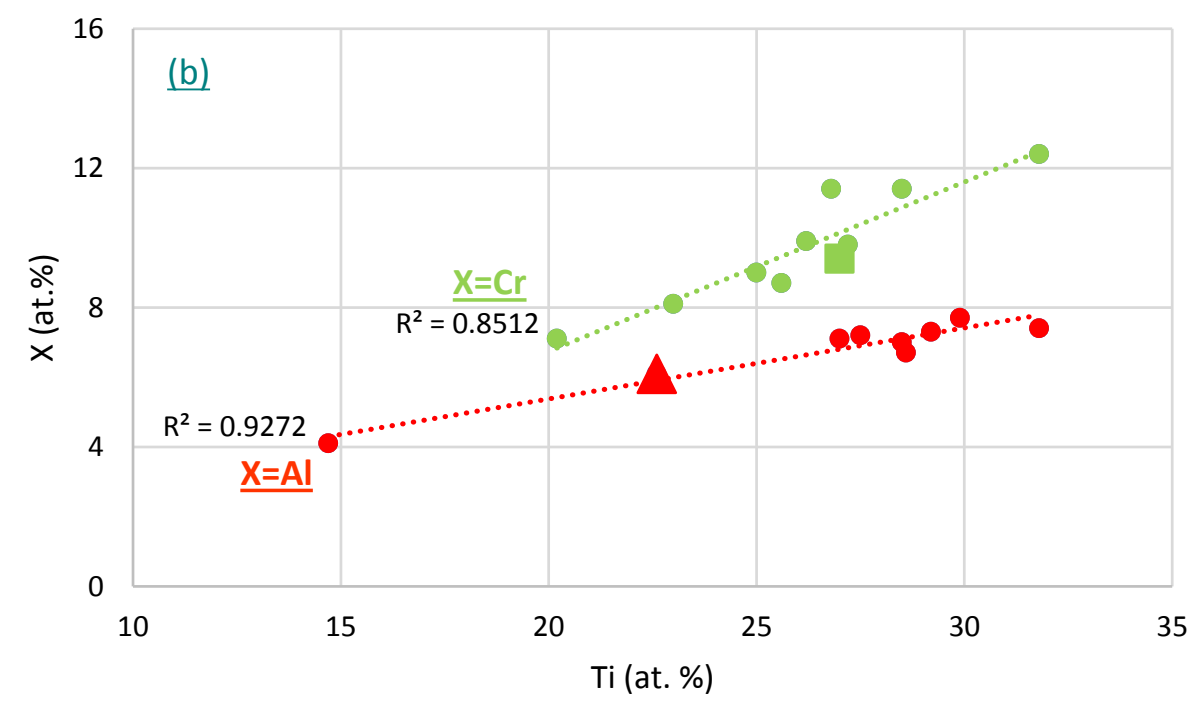

(b)

Figure 9. Data for solute element $\mathrm{X}=\mathrm{Al}$ or $\mathrm{Cr}$ in $\mathrm{Nb}_{\mathrm{ss}}$ (a) in cast and (b) heat treated $\mathrm{KZ}$ series alloys (data is shown by filled circles), and in the NbSiTiHf-5Al and NbSiTiHf-5Al-5Cr alloys. The data for $\mathrm{X}=\mathrm{Al}$ or $\mathrm{Cr}$ in $\mathrm{Nb}_{\mathrm{ss}}$ in $\mathrm{NbSiTiHf}-5 \mathrm{Al}-5 \mathrm{Cr}$ and $\mathrm{NbSiTiHf}-5 \mathrm{Al}$ is shown by squares and triangles, respectively. Data for $\mathrm{X}=\mathrm{Al}$ or $\mathrm{Cr}$ are shown in red and green, respectively. The alloying elements in $\mathrm{KZ}$ series alloys are $\mathrm{Al}, \mathrm{Cr}, \mathrm{Si}, \mathrm{Ti}$, for alloy compositions see [25].

\subsection{Hardness and Young's Modulus}

Data for the nano-hardness and micro-hardness and the Young's moduli of $\mathrm{Nb}_{\mathrm{ss}}$ and $\mathrm{Nb}_{5} \mathrm{Si}_{3}$ for heat treated alloys are compared in Table 3. The microhardness (mHV) is lower than the nano-hardness (nHV), in agreement with the literature [39]. For KZ type alloys [25] data from our research group gives $\mathrm{mHV}_{\mathrm{Nbss}}=0.7545\left(\mathrm{nHV}_{\mathrm{Nbss}}\right)$ and $\mathrm{mHV}_{\mathrm{Nb} 5 \mathrm{Si} 3}=0.633\left(\mathrm{nHV}_{\mathrm{Nb} 5 \mathrm{Si} 3}\right)$. It was not possible to measure the microhardness of the $\mathrm{Nb}_{\mathrm{ss}}$ and $\mathrm{Nb}_{5} \mathrm{Si}_{3}$ in the heat treated alloy NbSiTiHf-5Al-5Cr (the different phases could not be distinguished) and the nano-hardness and micro-hardness of the same phases in the 
heat treated alloy NbSiTiHf-5Al. The values given in bold italics for $\mathrm{Nb}_{\mathrm{ss}}$ and $\mathrm{Nb}_{5} \mathrm{Si}_{3}$ in Table 3 were calculated using the above relationships. The hardness data for the $\mathrm{Nb}_{\mathrm{ss}}$ shows that the synergy of $\mathrm{Al}$ and $\mathrm{Cr}$ has a stronger hardening effect than that between $\mathrm{Al}, \mathrm{Cr}$, and $\mathrm{Hf}$. The micro-hardness of binary (unalloyed) $\beta \mathrm{Nb}_{5} \mathrm{Si}_{3}$ is $1360 \mathrm{HV}$ [34]. The data in Table 3 shows that $(\mathrm{Nb}, \mathrm{Ti})_{5}(\mathrm{Si}, \mathrm{Al})_{3},(\mathrm{Nb}, \mathrm{Ti}, \mathrm{Cr})_{5}(\mathrm{Si}, \mathrm{Al})_{3}$, and $(\mathrm{Nb}, \mathrm{Ti}, \mathrm{Cr}, \mathrm{Hf})_{5}(\mathrm{Si}, \mathrm{Al})_{3}$ have hardness lower than $1360 \mathrm{HV}$ and that the substitution of $\mathrm{Nb}$ only by $\mathrm{Ti}$ and of $\mathrm{Si}$ only by $\mathrm{Al}$ has the smallest negative effect on the hardness of $\mathrm{Nb}_{5} \mathrm{Si}_{3}$ (see [34]).

The Young's moduli of $\mathrm{Nb}, \alpha \mathrm{Nb}_{5} \mathrm{Si}_{3}$, and $\beta \mathrm{Nb}_{5} \mathrm{Si}_{3}$, respectively are 101.9, 291, and $269 \mathrm{GPa}$ [40]. The data in Table 3 shows that the synergy of $\mathrm{Al}, \mathrm{Cr}$, and Ti had a stronger negative effect compared with the synergies between $\mathrm{Al}$ and $\mathrm{Ti}$ and between $\mathrm{Al}, \mathrm{Cr}, \mathrm{Hf}$, and Ti. Furthermore, the data for the $\mathrm{Nb}_{5} \mathrm{Si}_{3}$ in Table 3 is in agreement with the calculations that showed higher modulus for binary (unalloyed) $\alpha \mathrm{Nb}_{5} \mathrm{Si}_{3}$ than $\beta \mathrm{Nb}_{5} \mathrm{Si}_{3}$. Calculations in [40] for $\mathrm{Nb}_{5} \mathrm{Si}_{3}$ alloyed with Ti showed that when 12.5 at.\% Ti substitutes $\mathrm{Nb}$ in the $\mathrm{Nb}_{5} \mathrm{Si}_{3}$, the moduli of $\alpha\left(\mathrm{Nb}_{50} \mathrm{Ti}_{12.5}\right) \mathrm{Si}_{37.5}$ and $\beta\left(\mathrm{Nb}_{50} \mathrm{Ti}_{12.5}\right) \mathrm{Si}_{37.5}$ were 313.8 and $238.5 \mathrm{GPa}$, respectively. The data in Table 3 for the alloy KZ7 would suggest that the substitution of $\mathrm{Nb}$ by Ti, and $\mathrm{Si}$ by $\mathrm{Al}$, reduced the modulus of $\alpha \mathrm{Nb}_{5} \mathrm{Si}_{3}$. The same was the case for the $\beta \mathrm{Nb}_{5} \mathrm{Si}_{3}$ when $\mathrm{Nb}$ was substituted by Ti, $\mathrm{Cr}$, and $\mathrm{Hf}$ and $\mathrm{Si}$ by $\mathrm{Al}$ (data for the alloy NbSiTiHf-5Al-5Cr).

\subsection{Oxidation}

When the isothermal oxidation in air of the alloys NbSiTiHf-5Al and NbSiTiHf-5Al-5Cr at $800{ }^{\circ} \mathrm{C}$ and $1200{ }^{\circ} \mathrm{C}$ is compared with the alloys YG1, YG2, YG3, KZ4, KZ5, and KZ7, at both temperatures the weight gains of the alloys NbSiTiHf-5Al and NbSiTiHf-5Al-5Cr after $100 \mathrm{~h}$ oxidation were lower than the other alloys (Table S3 in Supplemental data where the nominal compositions of the aforementioned alloys are given).

At $800{ }^{\circ} \mathrm{C}$ the synergy of $\mathrm{Al}, \mathrm{Hf}$, and Ti was most effective in the alloy NbSiTiHf-5Al where pest oxidation was suppressed and a thin and adherent scale formed. The data for the alloy $\mathrm{NbSiTiHf}-5 \mathrm{Al}-5 \mathrm{Cr}$ would suggest that the addition of $\mathrm{Cr}$ had a negative effect (early stages of pest oxidation, see Section 3.3) even though the weight gain after $100 \mathrm{~h}$ was smaller than that of the alloy NbSiTiHf-5Al. This effect was attributed to Cr. Among the KZ series alloys [25] the alloy KZ7 exhibited the best isothermal oxidation in air at $800{ }^{\circ} \mathrm{C}$ and higher oxidation rates were observed in alloys where $\mathrm{Al}$ and $\mathrm{Cr}$ were present simultaneously.

The mass gain of the alloy KZ5 (Al and Cr but no Hf) was about $0.030 \mathrm{~g} / \mathrm{cm}^{2}$ after $85 \mathrm{~h}$ at $800{ }^{\circ} \mathrm{C}$. The data for the alloy NbSiTiHf-5Al-5Cr showed that the addition of Hf reduced the weight gain significantly but did not change the oxidation kinetics. Comparison of the oxidised specimens of the alloys KZ5 and NbSiTiHf-5Al-5Cr showed that the synergy of $\mathrm{Hf}$ with $\mathrm{Al}, \mathrm{Cr}$, and Ti also did not improve the adherence of the scale. However, the vol.\% of $\mathrm{Nb}_{\mathrm{ss}}$ in the alloy KZ5 (about 52\%) was higher than that in the alloy NbSiTiHf-5Al-5Cr (about $42 \%$ ). The $\mathrm{Nb}_{\mathrm{ss}}$ is known to have a negative effect on oxidation when its volume fraction increases in $\mathrm{Nb}$-silicide based alloys [5].

At $800{ }^{\circ} \mathrm{C}$ the $\mathrm{Nb}_{\mathrm{ss}}$ was contaminated by oxygen even in the bulk of both alloys, but the severity of contamination decreased with distance from the scale/substrate interface. $\mathrm{The} \mathrm{Nb}_{5} \mathrm{Si}_{3}$ was also contaminated by oxygen but only in the diffusion zone and its contamination was less severe compared with the $\mathrm{Nb}_{\mathrm{ss}}$.

At $1200^{\circ} \mathrm{C}$ none of the alloys produced a stable spall resistant scale, the alloy NbSiTiHf-5Al gained the lowest weight among the alloys YG1, YG2, YG3, KZ4, KZ5, KZ7 (see Table S3 in Supplemental data for nominal compositions of alloys) and NbSiTiHf-5Al-5Cr, but the oxidation of the alloy NbSiTiHf-5Al-5Cr was considered better as improvement of scale adhesion was observed (Table S3 in Supplemental data). Alloying Nb-24Ti-18Si based alloys with Al, Cr, Hf individually (alloys KZ7, KZ4 and YG3) did not improve the adhesion of the scale which spalled off from all sides of the cube shaped oxidation specimens. The same spallation was observed when $\mathrm{Al}$ and $\mathrm{Cr}$ and $\mathrm{Al}$ and $\mathrm{Hf}$ were present simultaneously in the alloys $\mathrm{KZ} 5$ and NbSiTiHf-5Al, respectively. Evidence for improved scale adhesion was provided only by the alloy NbSiTiHf-5Al-5Cr, where $\mathrm{Al}, \mathrm{Cr}$, and $\mathrm{Hf}$ were in synergy with Ti. Improvement in scale adhesion with the addition of $\mathrm{Sn}$ has been reported in [5] 
for Nb-24Ti-18Si-5Al-5Cr-5Hf-5Sn-2Mo but not for MASC-xSn alloys in [41], where $\mathrm{x}=2,4,5,6,8$ (the nominal composition of the MASC alloy is Nb-25Ti-16Si-8Hf-2Al-2Cr, [1]). Alloy design/selection research in our group [2] has indicated that stable spall resistant scales can form with the addition of metalloid element in Nb-Si-TM-RM-Al based alloys [42-44], where TM = transition metal and $\mathrm{RM}=$ refractory metal.

At $1200^{\circ} \mathrm{C}$ the $\mathrm{Nb}_{\mathrm{ss}}$ was not contaminated by oxygen in the bulk of the alloy NbSiTiHf-5Al-5Cr , but the severity of the contamination of the $\mathrm{Nb}_{\mathrm{ss}}$ increased close to the scale/substrate interface (Table $\mathrm{S} 2$ in Supplemental data). The $\mathrm{Nb}_{5} \mathrm{Si}_{3}$ was also contaminated by oxygen more severely compared with the oxidation at $800{ }^{\circ} \mathrm{C}$ and its contamination was less severe compared with the $\mathrm{Nb}_{\mathrm{ss}}$. The data for the alloy NbSiTiHf-5Al-5Cr would thus suggest that at $1200^{\circ} \mathrm{C}$ the synergy of $\mathrm{Al}, \mathrm{Cr}$, and $\mathrm{Hf}$ with Ti also was effective for reducing the contamination of the bulk of the alloy by interstitials. This was attributed to the scavenging of oxygen by $\mathrm{Hf}$ and the reduced diffusivity of oxygen from the synergy of $\mathrm{Al}$ and $\mathrm{Hf}[30]$.

It is not possible to compare the cracking of the substrate just below the scales formed on the two alloys at 800 and $1200{ }^{\circ} \mathrm{C}$ because of the spallation of the thicker scales at the latter temperature (see Section 3.4). It is highly likely that at the higher temperature (i) the plasticity of the oxide(s) could be enhanced, (ii) there could be some plastic deformation of the substrate, and as oxidation progressed, (iii) the fracture behaviour of the $\mathrm{Nb}_{\mathrm{ss}}$ and $\mathrm{Nb}_{5} \mathrm{Si}_{3}$ could vary with changes in the composition of the phases [31], and (iv) the mechanical properties of $\mathrm{Nb}_{5} \mathrm{Si}_{3}$ could also change with changing composition [40]. Thus, it is suggested that the deformation of the scale and substrate just below it could have been affected be one or more of (i) to (iv).

In the oxides of the scales formed on both the alloys NbSiTiHf-5Al and NbSiTiHf-5Al-5Cr at 800 and $1200{ }^{\circ} \mathrm{C}$ the presence of $\mathrm{Al}$ niobate was not indicated by XRD (Figure S7 in the Supplemental data). The latter oxide was observed in the scale formed on the alloys KZ7 (=Nb-24Ti-18Si-5Al [25]) and KZ5 (=Nb-24Ti-18Si-5Al-5Cr [25]) [3] but not on the Hf containing alloy JG4 (=Nb-24Ti-18Si-5Al-5Cr-5Hf-2Mo [5]). This would suggest that the suppression of the formation of $\mathrm{Al}$ niobates in the scale of the alloys NbSiTiHf-5Al and NbSiTiHf-5Al-5Cr could be attributed to the addition of Hf.

The oxidation of the single crystal Ni-based superalloy CMSX4 at $815{ }^{\circ} \mathrm{C}$ is parabolic with $\mathrm{k}_{\mathrm{p}}=4 \times 10^{-14} \mathrm{~g}^{2} \mathrm{~cm}^{-4} \mathrm{~s}^{-1}$ and the weight gain is about $0.05 \mathrm{mg} / \mathrm{cm}^{2}$ after $50 \mathrm{~h}$. At $1200{ }^{\circ} \mathrm{C}$ the oxidation also is parabolic with rate constant $\mathrm{k}_{\mathrm{p}}=4 \times 10^{-12} \mathrm{~g}^{2} \mathrm{~cm}^{-4} \mathrm{~s}^{-1}$ and the weight gain is about 1 to $4 \mathrm{mg} / \mathrm{cm}^{2}$ after $50 \mathrm{~h}$. The polycrystalline $\mathrm{Nb}$-silicide based alloys NbSiTiHf-5Al and NbSiTiHf-5Al-5Cr did not match the oxidation of CMSX4.

\section{Conclusions}

In this paper the alloys Nb-24Ti-18Si-5Al-5Hf (alloy NbSiTiHf-5Al) and Nb-24Ti-18Si-5Al-5Cr-5Hf (alloy NbSiTiHf-5Al-5Cr) were studied in the as-cast and heat-treated conditions and after isothermal oxidation for $100 \mathrm{~h}$ at 800 and $1200^{\circ} \mathrm{C}$. The alloys were compared with alloys without $\mathrm{Hf}$ addition. The conclusions of the research are as follows:

1. In both alloys there was macrosegregation of $\mathrm{Si}$ (MACSi) and $\mathrm{Ti}$ (MACTi). The simultaneous addition of $\mathrm{Al}, \mathrm{Hf}$, and Ti in the alloy NbSiTiHf-5Al resulted in the highest macrosegregation of Si.

2. In both alloys the $\mathrm{Nb}_{\mathrm{ss}}+\beta \mathrm{Nb}_{5} \mathrm{Si}_{3}$ eutectic was formed in the parts of the buttons where the melt had not solidified under the highest cooling rates.

3. The $\beta \mathrm{Nb}_{5} \mathrm{Si}_{3}$ and $\gamma \mathrm{Nb}_{5} \mathrm{Si}_{3}$ were formed in the cast alloy NbSiTiHf-5Al and only the $\beta \mathrm{Nb}_{5} \mathrm{Si}_{3}$ in the cast alloy NbSiTiHf-5Al-5Cr . The same compounds were present in the heat treated microstructures of the two alloys where separate $\mathrm{Hf}$ rich $\mathrm{Nb}_{5} \mathrm{Si}_{3}$ grains formed, particularly in the alloy NbSiTiHf-5Al-5Cr.

4. The $\mathrm{Nb}_{\mathrm{ss}}$ was stable in both alloys. Hafnium and $\mathrm{Ti}$ rich $\mathrm{Nb}_{\mathrm{ss}}$ was formed only in the cast alloy NbSiTiHf-5Al-5Cr. 
5. The $\mathrm{Si}$ and $\mathrm{Al}$ concentrations in $\mathrm{Nb}_{5} \mathrm{Si}_{3}$ respectively decreased and increased with increasing $\mathrm{Ti}$ concentration. The $\mathrm{Hf}$ concentration in the $\mathrm{Nb}_{5} \mathrm{Si}_{3}$ exhibited a stronger relationship with $\mathrm{Nb}$ than Ti .

6. The synergy of $\mathrm{Al}$ and $\mathrm{Cr}$ had a stronger hardening effect in the $\mathrm{Nb}_{\mathrm{ss}}$ than that between $\mathrm{Al}, \mathrm{Cr}$, and Hf. The synergy of $\mathrm{Al}, \mathrm{Cr}$, and Ti had a stronger negative effect on the Young's modulus of the $\mathrm{Nb}_{\mathrm{ss}}$ compared with that of $\mathrm{Al}, \mathrm{Cr}, \mathrm{Hf}$, and Ti. When $\mathrm{Nb}$ was substituted by Ti, $\mathrm{Cr}$, and $\mathrm{Hf}$ and $\mathrm{Si}$ by $\mathrm{Al}$ the Young's modulus of the $\beta \mathrm{Nb}_{5} \mathrm{Si}_{3}$ was reduced compared with the unalloyed silicide.

7. After $100 \mathrm{~h}$ at $800^{\circ} \mathrm{C}$ both alloys did not suffer from catastrophic pest oxidation. Contamination of the $\mathrm{Nb}_{\mathrm{ss}}$ and $\mathrm{Nb}_{5} \mathrm{Si}_{3}$ by oxygen was observed in both alloys, with that of the former phase being more severe. The $\mathrm{Nb}_{5} \mathrm{Si}_{3}$ was contaminated only in the diffusion zone. The $\mathrm{Nb}_{\mathrm{ss}}$ was contaminated in the bulk of both alloys.

8. At $1200^{\circ} \mathrm{C}$ there was spallation of the scale formed on both alloys, which was more severe for the alloy NbSiTiHf-5Al. In both alloys the contamination of $\mathrm{Nb}_{5} \mathrm{Si}_{3}$ and $\mathrm{Nb}_{\mathrm{ss}}$ by oxygen was increased slightly compared with $800{ }^{\circ} \mathrm{C}$, and the silicide was not contaminated by oxygen in the bulk. The $\mathrm{Nb}_{\mathrm{ss}}$ was not contaminated by oxygen only in the bulk of the alloy NbSiTiHf-5Al-5Cr.

Supplementary Materials: The following are available online at http:/ /www.mdpi.com/1996-1944/11/9/1579/ s1, Table S1: EPMA analysis data (at.\%) for phases in the alloy NbSiTiHf-5Al-5Cr after isothermal oxidation at $800{ }^{\circ} \mathrm{C}$, Table S2: EPMA analysis data (at.\%) for phases in the alloy NbSiTiHf-5Al-5Cr after isothermal oxidation at $1200{ }^{\circ} \mathrm{C}$, Table S3: Comparison of the isothermal oxidation of the alloys NbSiTiHf-5Al and NbSiTiHf-5Al-5Cr with other $\mathrm{Nb}$ silicide based alloys, Figure S1: X-ray diffractograms of the (a) as cast and (b) heat treated alloy NbSiTiHf-5Al and (c) cast and (d) heat treated alloy NbSiTiHf-5Al-5Cr. The non-indexed peaks correspond to un-identified phase(s), Figure S2: Specimens of the alloys NbSiTiHf-5Al (a) and NbSiTiHf-5Al-5Cr (b) after $100 \mathrm{~h}$ isothermal oxidation at $80{ }^{\circ} \mathrm{C}$, Figure S3: Specimens of the alloys NbSiTiHf-5Al (a) and NbSiTiHf-5Al-5Cr (b) after $100 \mathrm{~h}$ isothermal oxidation at $1200^{\circ} \mathrm{C}$, Figure S4: Isothermal oxidation data for the alloy NbSiTiHf-5Al (a) $800{ }^{\circ} \mathrm{C}$, (b) $1200^{\circ} \mathrm{C}$, Figure S5: Isothermal oxidation data for the alloy NbSiTiHf-5Al-5Cr (a) $800^{\circ} \mathrm{C},(\mathrm{b}) 1200^{\circ} \mathrm{C}$, Figure S6: BSE images of cross sections of the alloy NbSiTiHf-5Al after isothermal oxidation (a) at $800{ }^{\circ} \mathrm{C}$ and (b) at $1200^{\circ} \mathrm{C}$, Figure S7: XRD data for the alloy NbSiTiHf-5Al (a) glancing angle data (GXRD, $\theta=5$ degrees) for 800 ${ }^{\circ} \mathrm{C}$, (b) powder XRD data from the spalled off scale at $120{ }^{\circ} \mathrm{C}$.

Author Contributions: Experimental work J.N. and M.G.; Supervision C.U. and P.T.; Formal analysis J.N., M.G., C.U. and P.T.; Draft preparation J.N. and M.G.; Review C.U. and P.T.; Final paper J.N., M.G., C.U. and P.T.

Funding: This research was funded by the EPSRC (EP/H500405/1, EP/L026678/1) and Rolls-Royce Plc.

Acknowledgments: The support of this work by the University of Sheffield, Rolls-Royce Plc, and EPSRC is gratefully acknowledged.

Conflicts of Interest: The authors declare no conflict of interest.

\section{References}

1. Bewlay, B.P.; Jackson, M.R.; Subramanian, P.R.; Zhao, J.-C. A Review in Very-High Temperature Nb-Silicide-Based Composites. Metall. Mater. Trans. A 2003, 34, 2043-2052. [CrossRef]

2. Tsakiropoulos, P. On Niobium silicide based alloys: Alloy design and selection. Materials 2018, 11, 844 . [CrossRef] [PubMed]

3. Jackson, M.R.; Bewlay, B.P.; Zhao, J.C. Niobium-Silicide Based Composites Resistant to High Temperature Oxidation. U.S. Patent 6,913,655, B2, 5 July 2005.

4. Menon, E.S.K.; Mendiratta, M.G.; Dimiduk, D.M. High temperature oxidation mechanisms in Nb-silicide bearing multicomponent alloys. Struct. Intermet. 2001, 591-600.

5. Geng, J.; Tsakiropoulos, P. A study of the microstructure and oxidation of Nb-Si-Cr-Al-Mo in situ composites alloyed with Ti, Hf and Sn. Intermetallics 2007, 15, 382-395. [CrossRef]

6. Liu, A.; Sun, L.; Li, S.; Han, Y. Effect of Cerium on microstructure and high temperature oxidation resistance of an Nb-Si system in situ composite. J. Rare Earths 2007, 25, 474-479. [CrossRef]

7. Wang, J.; Guo, X.; Guo, J. Effects of B on the microstructure and oxidation resistance of Nb-Ti-Si based ultra-high temperature alloy. Chin. J. Aeronaut. 2009, 22, 544-550.

8. Gaillard-Allemand, B.; Vilasi, M.; Belmonte, T.; Steinmetz, J. Silicide coatings for Niobium: Mechanisms of chromium and silicon co-deposition by pack cementation. Mater. Sci. Forum 2001, 369, 727-734. [CrossRef]

9. Chen, C.; Zhou, C.; Gong, S.; Li, S.; Zhang, Y.; Xu, H. Deposition of Cr-modified silicide coatings on Nb-Si system intermetallics. Intermetallics 2007, 15, 805-809. [CrossRef] 
10. Tian, X.; Guo, X. Structure and oxidation behavior of Si-Y co-deposition coatings on an Nb silicide based ultra-high temperature alloy prepared by pack cementation technique. Surf. Coat. Technol. 2009, 204, 313-318. [CrossRef]

11. Tabaru, T.; Kim, J.-H.; Shobu, K.; Sakamoto, M.; Hirai, H.; Hanada, S. Development of Mo(Si,Al $)_{2}$ base oxidation resistant coating on Nb base structural materials. Metall. Mater. Trans. 2005, 36, 617-626. [CrossRef]

12. Yao, D.; Gong, W.; Zhou, C. Development and oxidation resistance of air plasma sprayed Mo-Si-Al coating on an $\mathrm{Nb}_{\mathrm{ss}} / \mathrm{Nb}_{5} \mathrm{Si}_{3}$ in situ composite. Corros. Sci. 2010, 52, 2603-2611. [CrossRef]

13. Majumdar, S.; Sengupta, P.; Kale, G.B.; Sharma, I.G. Development of multilayer oxidation resistant coatings on niobium and tantalum. Surf. Coat. Technol. 2006, 200, 3713-3718. [CrossRef]

14. Jackson, M.; Subramanian, P.; Zhao, J.-C.; Bewlay, B.; Darolia, R.; Schafrik, R. Turbine Blade for Extreme Temperature Conditions. U.S. Patent 7,189,459, 13 March 2007.

15. Jehanno, P.; Kestler, M.; Venskutonis, A.; Boning, M.; Heilmaier, M.; Bewlay, B.; Jackson, M. Assessment of a powder metallurgical route for refractory metal silicide alloys. Metal. Mater. Trans. 2005, 36, 515-523. [CrossRef]

16. Murakami, T.; Sasaki, S.; Ichikawa, K.; Kitahara, A. Microstructure, mechanical properties and oxidation behaviour of $\mathrm{Nb}-\mathrm{Si}-\mathrm{Al}$ and $\mathrm{Nb}-\mathrm{Si}-\mathrm{N}$ powder compacts prepared by spark plasma sintering. Intermetallics 2001, 9, 621-627. [CrossRef]

17. Huang, Q.; Guo, X.P.; Kang, Y.W.; Song, J.X.; Qu, S.Y.; Han, Y.F. Microstructures and mechanical properties of directionally solidified multi-element Nb-Si alloy. Prog. Nat. Sci. Mater. Int. 2011, 21, 146-152. [CrossRef]

18. Sekido, N.; Kimura, Y.; Miura, S.; Mishima, Y. Microstructure development of unidirectionally solidified $(\mathrm{Nb}) / \mathrm{Nb}_{3} \mathrm{Si}$ eutectic alloys. Mater. Sci. Eng. A 2007, 444, 51-57. [CrossRef]

19. Begley, R.T.; Bechtold, J.H. Effect of alloying on the mechanical properties of Niobium. J. Less-Common Met. 1961, 3, 1-12. [CrossRef]

20. Argent, B.B.; Phelps, B. The oxidation of Niobium-titanium and Niobium-molybdenum alloys. J. LessCommon Met. 1960, 2, 181-190. [CrossRef]

21. Davidson, D.L.; Chan, K.S. The failure and fracture resistance of a Nb-Cr-Ti-Al alloy. Metall. Mater. Trans. A 1999, 30, 2007-2018. [CrossRef]

22. Okamoto, H. Phase Diagrams for Binary Alloys: Desk Handbook, 2nd; ASM International: Geauga County, $\mathrm{OH}$, USA, 2000.

23. Jackson, M.R.; Bewlay, B.P.; Briant, C.L. Creep Resistant Nb-Silicide Based Two-Phase Composites. U.S. Patent 6,447,623 B1, 10 September 2002.

24. Bewlay, B.P.; Sitzman, S.D.; Brewer, L.N.; Jackson, M.R. Analyses of eutectoid phase transformations in $\mathrm{Nb}$-silicide in situ composites. Microsc. Microanal. 2004, 10, 470-480. [CrossRef] [PubMed]

25. Zelenitsas, K.; Tsakiropoulos, P. Study of the role of $\mathrm{Al}$ and $\mathrm{Cr}$ additions in the microstructure of $\mathrm{Nb}$-Ti-Si in situ composites. Intermetallics 2005, 13, 1079-1095. [CrossRef]

26. Grammenos, I.; Tsakiropoulos, P. Study of the role of $\mathrm{Al}, \mathrm{Cr}$ and $\mathrm{Ti}$ additions in the microstructure of $\mathrm{Nb}-18 \mathrm{Si}-5 \mathrm{Hf}$ base alloys. Intermetallics 2010, 18, 242-253. [CrossRef]

27. Tsakiropoulos, P. Alloying and hardness of eutectics with $\mathrm{Nb}_{\mathrm{ss}}$ and $\mathrm{Nb}_{5} \mathrm{Si}_{3}$ in $\mathrm{Nb}$-silicide based alloys. Materials 2018, 11, 592. [CrossRef] [PubMed]

28. Oliver, W.C.; Pharr, G.M. An improved technique for determining hardness and elastic modulus using load and displacement sensing indentation experiments. J. Mater. Res. 1992, 6, 1564-1583. [CrossRef]

29. Tsakiropoulos, P. On the macrosegregation of silicon in niobium silicide based alloys. Intermetallics 2014, 55, 95-101. [CrossRef]

30. Ghosh, G.; Olson, G.B. Integrated design of Nb-based superalloys: Ab initio calculations, computational thermodynamics and kinetics and experimental results. Acta Mater. 2007, 55, 3281-3303. [CrossRef]

31. Chan, K.S. Alloying effects on fracture mechanisms in Nb-based intermetallic in-situ composites. Mater. Sci. Eng. 2002, 337, 59-66. [CrossRef]

32. Tian, Y.X.; Guo, J.T.; Zhou, L.Z.; Cheng, G.M.; Ye, H.Q. Microstructure and room temperature fracture toughness of cast $\mathrm{Nb}_{\mathrm{ss}}$ / silicide composites alloyed with Hf. Mater. Lett. 2008, 62, 2657-2660. [CrossRef]

33. Tsakiropoulos, P. On Nb silicide based alloys: Part I-The bcc Nb solid solution. J Alloys Compd. 2017, 708, 961-971. [CrossRef]

34. Tsakiropoulos, P. On the alloying and properties of tetragonal $\mathrm{Nb}_{5} \mathrm{Si}_{3}$ in $\mathrm{Nb}$-silicide based alloys. Materials 2018, 11, 69. [CrossRef] [PubMed] 
35. Raghavan, V. Al-Nb-Si (Aluminum-Niobium-Silicon). J. Phase Equilib. Diffus. 2006, 27, 163-165.

36. Batzner, C.; Beuers, J.; Hoch, M.; Schmid-Fetzer, R. Ternary Alloys; VCH: New York, NY, USA, 1993; pp. 370-374.

37. Schob, O.; Nowotny, H.; Benesovsky, F. The ternary systems formed by Ti, Zr and Hf with $\mathrm{Al}$ and $\mathrm{Si}$. Planseeber Pulvermetall 1962, 10, 65-71.

38. Bulanova, M.; Tretyachenko, L.; Golovkova, M.; Meleshevich, K. Phase equilibria in the $\alpha$-Ti-Al-Si region of the Ti-Si-Al system. J. Phase Equilib. Diffus. 2004, 25, 209-229. [CrossRef]

39. Kim, J.-H.; Tabaru, T.; Hirai, H. Evaluation technique of the hardness and elastic modulus of materials with fine microstructures. Mater. Trans. 2003, 44, 673-676. [CrossRef]

40. Papadimitriou, I.; Utton, C.; Tsakiropoulos, P. The impact of Ti and temperature on the stability of $\mathrm{Nb}_{5} \mathrm{Si}_{3}$ phases: A first-principles study. Sci. Technol. Adv. Mater. 2017, 18, 467-479. [CrossRef] [PubMed]

41. Knittel, S.; Mathieu, S.; Portebois, L.; Vilasi, M. Effect of tin addition on Nb-Si-based in situ composites. Part II: Oxidation behavior. Intermetallics 2104, 47, 43-52. [CrossRef]

42. Thandorn, T. Study of the effect of metalloid element addition on the properties of Nb-silicide based alloys. University of Sheffield: Sheffield, UK, Unpublished work. 2010.

43. Bywater, G. Study of the effect of metalloid element addition on the oxidation of Nb-silicide based alloys. University of Sheffield: Sheffield, UK, Unpublished work. 2013.

44. Zhao, J. Study of the effect of refractory metal addition on the properties of Nb-silicide based alloys. University of Sheffield: Sheffield, UK, Unpublished work. 2017.

(C) 2018 by the authors. Licensee MDPI, Basel, Switzerland. This article is an open access article distributed under the terms and conditions of the Creative Commons Attribution (CC BY) license (http://creativecommons.org/licenses/by/4.0/). 